\title{
El camino hacia la guerra civil: El Salvador en 1979 y 1980
}

Héctor Grenni ${ }^{1}$

Recibido en octubre de 2014, aceptado en noviembre de 2014.

\begin{abstract}
Resumen
El presente artículo presenta los procesos, las dinámicas y las contradicciones que se dieron en la sociedad salvadoreña hacia fines de la década de los años 70, especialmente en los años 1979 y 1980. El escrito hace especial énfasis en las dinámicas a que dio lugar la evolución de las relaciones sociales y los conflictos que se suscitaron. En ese contexto, Monseñor Romero se convirtió en referente obligado de todo accionar social o político.
\end{abstract}

Palabras claves

Monseñor Romero, golpe de estado de 1979, El Salvador, represión.

\begin{abstract}
This article presents the processes, dynamics, and contradictions that took place in the Salvadoran society in the late 70s, particularly from 1979 to 1980. The emphasis is placed on the dynamics that gave origin to the evolution of the social relations and conflicts that happened during that time. In such context, Archbishop Romero became a required reference for all social and political activity.
\end{abstract}

Keywords:

Archbishop Romero, coup d'état in 1979, El Salvador, repression.

\section{Introducción}

Hay momentos en los que la historia de los países parece cargada de una gran 'densidad histórica'. De esta forma se suele definir los intensos meses de la segunda mitad de 1789 en París, que derivaron en la revolución francesa; o los días que precedieron al 17 de octubre de 1917 en Moscú y San Petersburgo², que derivaron en la revolución rusa.

En El Salvador, en los años 1979 y 1980 la historia cotidiana parecía cargada de

1. Héctor Grenni, Director de la Biblioteca Rafael Meza Ayau, Universidad Don Bosco, San Salvador. Email: hector.grenni@udb.edu.sv

2. Ver, por ejemplo, el interesantísimo libro sobre la revolución rusa de 1917 de John Reed, Diez días que estremecieron al mundo, Akal Ediciones, Madrid, Abril de 1996, ISBN-10: 8476001428. 
esa 'densidad histórica'. La efervescencia popular, la violencia de la represión de las fuerzas armadas y las policías, el agotamiento del sistema, la agudización de las contradicciones, el fracaso de los procesos democráticos y la voracidad de la oligarquía se unieron para crear esta 'densidad histórica' que se manifestó de formas variadas, las que llevaron al país a la guerra civil.

El período, uno de los de mayor efervescencia en la historia del país, tiene muchos 'actores principales': las clases campesinas, que cobraron un protagonismo que no habían tenido antes, salvo, quizá, en 1932; los militares, que se encontraron ante la posibilidad histórica de liderar un proceso de cambio único en la historia, dejando de lado la tradicional alianza con la oligarquía; las clases trabajadoras, cuyas organizaciones populares alcanzaron niveles de adhesión como nunca los habían tenido antes; la oligarquía, que no supo ver la oportunidad que se abría de dejar de lado sus privilegios para la construcción de una sociedad justa; los partidos políticos tradicionales, que, sumidos en una práctica corrupta de ejercer la democracia, se vieron superados por la militancia popular sin poder hacer frente a las exigencias de las mayorías marginadas; los medios de comunicación masiva, que no supieron entrever las oportunidades que se presentaban y permanecieron atados a una mezquina estrategia de sumisión a un sistema en el que se encontraban cómodos; y la Iglesia católica, que, sumida en un acelerado proceso de revisión de su forma de afrontar la realidad, vio cómo en su seno se abrían corrientes divergentes que la llevaban a un intenso y a veces ardoroso diálogo interno que puso en tela de juicio sus opciones tradicionales y su propia historia en el país.

Este trabajo se centrará en la evolución de estos ‘actores principales': la evolución de su pensamiento y sus acciones, los cambios, las contradicciones y los conflictos: en el fondo, su forma de entender la realidad que los rodeaba.

Sin embargo, la lupa de esta investigación se enfocará en el protagonismo asumido por el arzobispo de San Salvador, Monseñor Oscar Arnulfo Romero, que se convertirá en protagonista principal, referente no sólo para la Iglesia católica, sino para toda la población del país. En palabras de Jon Sobrino, "Desde aquel día, y como aquel día, en cualquier hecho importante que ocurrió en El Salvador, para seguirlo o para perseguirlo, siempre hubo que volver la vista hacia Monseñor Romero". ${ }^{3}$

\section{La persecución contra la Iglesia católica ${ }^{4}$}

3. López Vigil, María, 'Monseñor Romero, piezas para un retrato', UCA Editores, San Salvador, $5^{\text {a }}$ ed. 2001, pág. 161. El comentario de Sobrino alude al episodio del pueblo y la iglesia de Aguilares, ocupados por la Guardia Nacional durante un mes. La devolución de la iglesia tuvo momentos de fuerte tensión.

4. "Llegará un tiempo en El Salvador en que a los curas nos van a botar del país. Seremos culateados, matados, nos harán chingaste... y al final estallará una guerra. Y ustedes serán los responsables de la fe de sus comunidades. Prepárense cabalmente para esa hora y entiendan que ustedes sufrirán también ingratitudes.

Eso escuché como profecía a un cura que nos dio un cursillo de realidad nacional en Los Naranjos, mucho antes de que empezaran las grandes masacres. Y me entró una helazón." Testimonio de Alejandro Ortiz, recogido por María López Vigil, Monseñor Romero. Piezas para un retrato, UCA Editores, San Salvador, 2011, pág. 58. 
Uno de los primeros procesos que se dieron hacia fines de la década de los años 70 fue la represión contra la Iglesia católica. Esto forma parte de la creciente violencia represiva por parte de los gobiernos en El Salvador, en aumento desde mediados de la década y agudizada con la efervescencia popular. De hecho, Monseñor Romero, una vez instalado en San Salvador, denunció públicamente esta represión numerosas veces, en sus homilías y por medio de la radio del arzobispado. Su penúltima homilía, un día antes de su asesinato, culminó en un aplaudido y conocido llamado a cesar la represión.

En un contexto de urgencia de reformas profundas y violencia generalizada, la Iglesia católica comenzó a ser el blanco de una persecución cada vez más intensa. El asesinato de seis sacerdotes en los tres años de trabajo de Monseñor Romero en San Salvador y la hostilidad cada vez más manifiesta de los medios de difusión son pruebas de ello.

En los tres primeros meses de trabajo de Romero como arzobispo fueron asesinados dos sacerdotes: Rutilio Grande y Alfonso Navarro. La 'misa única', el distanciamiento del gobierno, las exigencias de aclaración de los asesinatos, fueron algunas de las consecuencias de estos actos. En los tres años de trabajo de Romero en San Salvador fueron asesinados seis sacerdotes.

La persecución se dirigió contra aquellos sacerdotes y catequistas que trabajaban en las comunidades eclesiales de base; algunos de ellos, estaban muy cercanos a la guerrilla, e incluso junto a ella. Es el caso de varios sacerdotes, como Miguel Ventura ${ }^{5}$ y el belga Rogelio Ponceele ${ }^{6}$. Ambos habían trabajado en la formación de las comunidades eclesiales de base, como muchos otros sacerdotes y catequistas. ${ }^{7}$

Ya desde principios de 1979, la radio del arzobispado incriminaba a la oligarquía salvadoreña como causante de esta campaña contra la Iglesia católica, porque

5. El sacerdote diocesano Miguel Ventura, párroco de Osicala, en el departamento de Morazán, fue capturado y torturado por las fuerzas armadas en noviembre de 1977. "No tenía duda alguna: mi muerte estaba próxima... Para evitar no sólo el miedo sino también lo que los militares me pedían, aceptar mi participación y la de Monseñor Romero en actos contra el gobierno, hice un esfuerzo para sintetizar frente a la muerte, mi vida. Y entonces supe por qué me tenían ahí torturado: hablé de justicia, hablé de libertad. En ese momento, acepté mi muerte: era el precio que tenía que pagar". Testimonio recogido por Cortina, María, El Salvador: Memoria Intacta, Editorial Geminis, sin otros datos editoriales, pág. 21.

6. El sacerdote diocesano Rogelio Ponceele convivió con la guerrilla del Ejército Revolucionario del Pueblo en el norteño Departamento de Morazán. Chávez Orellana, Brenda Ivonne, Historiografía de la literatura testimonial y su apogeo en El Salvador en la década de los 80's. Aplicación de características a obras modélicas, Trabajo de grado para optar al grado de Licenciatura en Letras, San Salvador, El Salvador, Universidad de El Salvador.

7. "Con su tesis de que la evangelización debe partir de un análisis de la realidad que cada comunidad vive, fue modificando la visión de los campesinos. Para muchos, lo que Miguel Ventura hizo fue abonar la tierra a 'los muchachos' del FMLN. Para él no fue sino colocar a la fe en su base antropológica. $O$, dicho a su manera, 'descubrirnos como seres humanos en una sociedad deshumanizada'" Cortina, María, El Salvador: Memoria Intacta, Editorial Geminis, sin otros datos editoriales, pág. 23. 
la mayoría de sus miembros habían tomado partido por los más pobres, ${ }^{8}$ siguiendo las indicaciones de los documentos de Medellín y Puebla. Específicamente, el documento de Puebla hizo una 'opción preferencial por los pobres'. Ello llevó a la oligarquía a dirigir su campaña especialmente contra el arzobispado de San Salvador.

En el marco de una sociedad salvadoreña profundamente dividida en clases, muchos sacerdotes habían preferido llevar a cabo su acción de evangelización entre los más pobres. Esta evangelización, siguiendo los lineamientos de Medellín y Puebla, llevaba inevitablemente a una toma de conciencia de que las desigualdades no eran cosa deseada por Dios, y por lo tanto, debían cambiarse. Muchas personas dirigieron su cristianismo hacia el campo de la justicia social, y muchas exteriorizaron esta opción en la militancia en las organizaciones populares.

Rápidamente, la persecución contra la Iglesia fue tomando características de una represión selectiva9 ${ }^{9}$, que comenzó a hacerse sentir ya desde 1977. Estos hechos despertaron la indignación, exteriorizada repetidas veces, de muchas personas de las clases marginadas y populares, entre las cuales la Iglesia conservaba un inmenso respeto. Esto motivó también la reacción internacional, que el gobierno trató de ocultar por medio de campañas de los medios de difusión que dominaba.

La oligarquía fomentó esta campaña valiéndose, generalmente, de los medios de información y de ataques selectivos realizados en la modalidad de 'escuadrones de la muerte'. Desde sus ámbitos diversos de actuación fomentaron una campaña de acusaciones contra la Iglesia, acusándola de fomentar la violencia, los enfrentamientos entre clases y las doctrinas comunistas que atentaban contra el orden establecido. Los medios de comunicación se prestaron al juego, dejando amplios espacios a estas exteriorizaciones. Los gobiernos de turno -el Poder Ejecutivo estuvo en manos de dos personas, y de dos Juntas Revolucionarias de Gobierno en los tiempos de Romero entre 1977 y 1980-, fueron sumamente complacientes con esta campaña, y los asesinatos no se investigaron ni se castigaron. ${ }^{10}$

8. "Esta parte minoritaria de la sociedad salvadoreña, aunque se confiesa todavía cristiana, católica, civilizada, humanista, ella precisamente inspira, fomenta, empuja y sanciona los asesinatos de aquellos sacerdotes que antes de haberse comprometido con los más pobres, respetaban, celebraban regalaban y, digámoslo también, usaban como últimos justificadores de sus privilegios." El Salvador entre el terror y la esperanza. Los sucesos de 1979 y su impacto en el drama salvadoreño de los años siguientes, Compilado por Rodolfo R. Campos, UCA Editores, San Salvador, 1982, pág. 384, programa del 7 de agosto de 1979.

9. "Ellos no matan a cualquiera: matan a los oprimidos concientizados y matan a los concientizadores de los oprimidos; matan a los campesinos aterrorizados y matan a los sacerdotes que acompañan el llanto y el dolor de los campesinos muertos". El Salvador entre el terror y la esperanza. Los sucesos de 1979 y su impacto en el drama salvadoreño de los años siguientes, Compilado por Rodolfo R. Campos, UCA Editores, San Salvador, 1982, pág. 385, programa del 7 de agosto de 1979.

10. "Asesina a sacerdotes quien en partidas de canasta les difama, calumnia, critica injustamente y crea ambiente contra ellos; asesina a representantes del Señor quien en fiestas sociales, entre trago y trago, los acusa de defender y propagar doctrinas contrarias a la Constitución, revolucionarias y anárquicas y crea ambiente de que los curas católicos son subversivos. 
En un contexto cada vez más polarizado, las acusaciones a la Iglesia se centraron en dos argumentos: la ruptura de las tradiciones y la apuesta por el marxismo. Estas acusaciones provenían de la oligarquía y, con frecuencia, de sectores tradicionales de la misma Iglesia. El arzobispo, al tiempo que favorecía las reformas que proponían las organizaciones populares, justificándolas en la fidelidad a los documentos del Concilio y de Medellín, rechazaba un cristianismo de corte espiritualista, sin contacto con la realidad y refugiada en el pietismo ${ }^{11}$.

El arzobispo no rehuyó el debate que la realidad le planteó, y habló de 'un tronco seco', 'museo de antigüedades',12 'tradicionalismo sin vida', ${ }^{13}$ refiriéndose a quienes se aferraban a las tradiciones proponiendo un cristianismo alejado de la referencia al contexto.

El 4 de agosto de 1979, pocos días antes de la publicación de su Cuarta Carta Pastoral y dos meses antes del golpe de estado de octubre, en momentos en que el presidente Carlos Humberto Romero buscaba la forma de salvar su credibilidad que la crisis nacional había cuestionado, y que su propuesta de diálogo en el Foro Nacional no lograba recuperar, fue asesinado el sacerdote Napoleón Macías, ${ }^{14}$

Asesina a sacerdotes quien para ganarse unos pesos, para merecer los favores de un empresario o gobierno, para ventilar su odio, escribe noticias y artículos falsos, mendaces, parciales, sin ningún rigor ni sin ninguna prueba, contra la misión, trabajo y apostolado de los sacerdotes católicos, y crea ambiente de que los sacerdotes son peligrosos enemigos de la patria.

Asesinan a los sacerdotes los consejeros y analistas que por pereza mental, por falta de talento o simplemente para estar a la moda, responsabilizan a los sacerdotes católicos de inspirar, fomentar y organizarla oposición política, las protestas callejeras y hasta el terrorismo y crean ambiente de que los sacerdotes deben ser eliminados. Asesinan a los sacerdotes las autoridades que los dejan a la merced de bandas armadas, inspiradas por el odio y la impotencia que proviene del total y vergonzoso fracaso del gobierno en la lucha contra los guerrilleros marxistas leninistas.

Las balas mortíferas las disparan matones a sueldo, asesinos profesionales pagados, empujados, permitidos, inspirados, fomentados, aplaudidos y sancionados por una parte de la respetable burguesía salvadoreña, sus aliados y servidores en todas las esferas del aparato estatal y del poder económico". El Salvador entre el terror y la esperanza. Los sucesos de 1979 y su impacto en el drama salvadoreño de los años siguientes, Compilado por Rodolfo R. Campos, UCA Editores, San Salvador, 1982, pág. 289-290, programa del 21 de junio de 1979, ante el asesinato del sacerdote palacios, el 20 de junio de 1979.

11. "Ojalá, queridos hermanos,, nos interesáramos por conocer lo que dice la Iglesia a partir del Concilio Vaticano II.Y eso no es haber roto con las tradiciones de veinte siglos, sino evolucionarlas a los tiempos modernos... mientras por una parte acusan a la Iglesia de marxista, se subversiva, por otra se quiere obligar a la Iglesia a una tradición sin inmanencia, es decir, una espiritualidad desencarnada, una predicación tipo (secta) protestante, que solamente se mantiene en las nubes, que canta salmos, que reza, pero que no se preocupa de las realidades temporales”. Homilía del 08.05.1977, citado por Márquez Ochoa, martirologio de Mons. Romero. Testimonio y catequesis martirial de la Iglesia salvadoreña, Comunidades Eclesiales de Base, San Salvador, sin fecha, pág. 148.

12. Homilía del 02.09.1977.

13. Homilía del 31.12.1978.

14. "Un sacerdote más que cae víctima de del odio ciego al cristianismo, a los que, siguiendo la 'opción fundamental' de la III Conferencia del Episcopado Latinoamericano en Puebla, se han dedicado a evangelizar con preferencia a los pobres. Un crimen más, un salvadoreño más que sufre la suprema injusticia de una muerte violenta, pero una víctima cualificada que descubre, por si hiciera falta, a los ojos del mundo, lo poco que valen las palabras y las promesas, aun las que provienen de las más altas autoridades del país." El Salvador entre el terror y la esperanza. Los sucesos de 1979 y su impacto en el drama salvadoreño de los años siguientes, Compilado por Rodolfo R. Campos, UCA Editores, San Salvador, 1982, pág. 384, programa del 7 de agosto de 1979. 
perteneciente a la diócesis de San Vicente. La inmediata reacción de Monseñor Romero, de Monseñor Rivera Damas, y de muchas personas, fieles de la Iglesia muchos de ellos, militantes de las organizaciones populares otros, encontró distintos medios de expresión. Fueron también numerosas las reacciones en el ámbito internacional y en las organizaciones populares.

La también inmediata reacción del embajador de Estados Unidos, Frank Devine tuvo inmensa repercusión: por venir de quien venía, por la contundencia de sus argumentos $^{15}$ y por el silencio de otros embajadores, entre ellos el embajador del Vaticano, el nuncio apostólico. ${ }^{16}$ Además, llamó poderosamente la atención el silencio de la Conferencia Episcopal, en una muestra más de su aguda división interna.

Ya desde mediados de 1979 comenzó una virulenta campaña de intimidación contra los sectores de la Iglesia católica vinculados a Monseñor Romero ${ }^{17}$ y las organizaciones populares. Las amenazas fueron frecuentes y públicas, el mismo arzobispo las sufrió y los medios de prensa se prestaron vilmente al juego.

La violencia se concretó contra los sacerdotes y contra las instalaciones del arzobispado que más molestaban al gobierno, y entre éstas, las instalaciones de la radio ISAX ${ }^{18}$, que semanalmente transmitía en vivo las homilías de las misas

15. "La declaración del embajador norteamericano es sobria pero firme. Se apoya fundamentalmente en el hecho de que frente a una injusticia manifiesta, frente a algo que viola no solamente la dignidad y el derecho de un salvadoreño, sino, ante todo, la dignidad y el derecho de un hombre, todo hombre está en la obligación de intervenir según sus capacidades. El que ve una injusticia y no la condena es reo parcial de esta injusticia y causante anónimo de que este tipo de injusticias se siga repitiendo con toda impunidad." El Salvador entre el terror y la esperanza. Los sucesos de 1979 y su impacto en el drama salvadoreño de los años siguientes, Compilado por Rodolfo R. Campos, UCA Editores, San Salvador, 1982, pág. 391, programa del 9 de agosto de 1979.

16. "Pensamos especialmente en lo que pudiera haber hecho el Nuncio de Su santidad, que si es embajador de la santa sede es también, en alguna medida, representante pastoral del papa. Tiene, por tanto, que actuar como el Papa actuaría aquí. Ni por un momento puede pensarse que si aquí viviera el Papa dejaría de protestar por las matanzas de campesinos y por los asesinatos de los sacerdotes. Cualesquiera sean los autores materiales e intelectuales de todas estas muertes injustas, cabe condenar la muerte injusta; más aún, es obligación condenarla". El Salvador entre el terror y la esperanza. Los sucesos de 1979 y su impacto en el drama salvadoreño de los años siguientes, Compilado por Rodolfo R. Campos, UCA Editores, San Salvador, 1982, pág. 391, programa del 9 de agosto de 1979.

17. "El señor nuncio de Costa Rica me ha avisado que el peligro de amenaza existe otra vez contra mí y me advierte que tenga cuidado." Monseñor Oscar Arnulfo Romero, Diario, edición a cargo del Arzobispado de San Salvador, San Salvador, pág. 384, nota del 23.02.1980. La nota es de mediados de febrero, poco más de un mes antes del asesinato del arzobispo.

18. "Me despiertan con una llamada urgente de la Hermana maría, desde Domus Mariae, paradecirme que ha estallado una bomba en la planta de la ISAX y que ha quedado completamente arruinada. Pregunté si había daños personales y me alegré de que sólo fueran de carácter material, lo cual tiene reparación. Esta misma noche y a la misma hora, como a las once de la noche, también estalló otra bomba en la biblioteca de la UCA, evidentemente, pues, se trata de maniobras de la extrema derecha contra la voz de la Iglesia y contra las exigencias de justicia social." Monseñor Oscar Arnulfo Romero, Diario, edición a cargo del Arzobispado de San Salvador, San Salvador, pág. 432, nota del 19.02.1980. La nota es de mediados de febrero, poco más de un mes antes del asesinato del arzobispo. 
de los domingos de Romero, y diariamente transmitían programas oficiales, donde se presentaba la postura del arzobispado ante la realidad cotidiana.

La violencia contra la Iglesia se manifestó también contra los sacerdotes jesuitas y los que estaban ligados a las comunidades eclesiales de base. Las instalaciones de la Universidad Centroamericana José Simeón Cañas (UCA) sufrieron varios atentados, hasta llegar al asesinato de su rector, su vicerrector y otros cuatro jesuitas en 1989.

Precisamente la ausencia de unanimidad por parte de la jerarquía de la Iglesia católica ante los asesinatos de los sacerdotes, llevó a muchas personas a pensar que fuesen parcialmente responsables de esas muertes: una demostración unánime de repudio hubiera detenido las intenciones de quienes mataban a los sacerdotes $^{19}$.

La magnitud de la represión indicaba claramente la magnitud de la crisis: el país se acercaba irremediablemente a la guerra civil. La incapacidad de contener a las fuerzas armadas por parte del presidente Romero, o, más aún, su permisividad, exigían elocuentemente una solución que no podía hacerse esperar.

La intolerancia de la oligarquía, que empujó a las fuerzas armadas a posiciones de fanatismo violento conducía rápidamente al país hacia el abismo de la guerra.

El contexto regional y nacional a fines de la década de los años 70: la preparación del golpe de 1979.

En julio de 1979 el sandinismo llegó al poder en Nicaragua. Con ello, los militantes de las organizaciones populares y la guerrilla alimentaron su imaginario colectivo con la proximidad de la 'sociedad socialista salvadoreña', 'una nueva Nicaragua', porque 'Si Nicaragua triunfó, El Salvador triunfará'. La oligarquía vio agrandarse sus temores y recelos, mientras el gobierno resucitaba su tesis del 'complot comunista internacional' y trataba de atenuar la efervescencia popular con concesiones que nadie atendía.

En el contexto nacional, el gobierno del general Carlos Humberto Romero tuvo que cargar con un profundo descontento popular y un también profundo descrédito institucional. El primero, por la crisis social que provocaban las necesidades insatisfechas, la estrechez de horizontes y el cierre de los espacios de participación, que derivaban en una creciente organización popular. El segundo, provocado por la incapacidad institucional de dar respuesta a los

19. "Sobre ellos recaerá en gran parte la responsabilidad-por grave falta de omisión- de cualquier muerte de sacerdote que siga, si es que no hacen pública protesta de esta campaña. Los asesinos se ven con las manos más libres por ese continuado silencio de cuatro obispos y un nuncio, más dispuestos a arreglar los asuntos de Cristo y de los cristianos en los despachos del gobierno y del poder que en las plazas y en los campos de los oprimidos." El Salvador entre el terror y la esperanza. Los sucesos de 1979 y su impacto en el drama salvadoreño de los años siguientes, Compilado por Rodolfo R. Campos, UCA Editores, San Salvador, 1982, pág. 288, programa del 21 de junio de 1979 
cuestionamientos, por la dudosa legitimidad de un gobierno nacido de elecciones abiertamente fraudulentas y por el uso indiscriminado de la violencia represiva.

Este contexto redujo los márgenes de maniobra del gobierno, que perdió toda iniciativa, cediéndolos a las organizaciones populares y a la naciente guerrilla armada y acentuando su aislamiento internacional. Al tiempo que arreciaba la represión, el presidente se enmarcó sin mucho margen en una política de defensa de los derechos humanos que nadie creía. El descrédito lo llevó a buscar fuera de las fronteras una legitimidad de la que carecía: en 1979 mandaba una representación a la Convención Interamericana de Derechos Humanos que se reunía en Costa Rica, firmaba la resolución de la Organización de los Estados Americanos (OEA) que definía la tortura como un acto contra los derechos humanos y viajaba a México en el mismo momento que las organizaciones populares tomaban la embajada de ese país.

En un intento por poner freno, precisamente, a esa violencia, el presidente promovió un diálogo nacional en el que invitaba a participar a la oposición: el Foro Nacional, 'para realizar un auténtico proceso de participación ciudadana en el hacer político nacional...' ${ }^{20}$ advirtiendo, al mismo tiempo, que no dejaría de lado la lucha contra el terrorismo y la subversión. El presidente invitaba a un diálogo que debía promover la participación ciudadana sin dejar de lado la represión... La invitación estaba viciada desde el comienzo, no tenía objetivos claros, no incluía a todas las fuerzas de oposición y estaba acompañada de una política autoritaria y represiva: la invitación no invitaba a la credibilidad. El Foro, destinado al fracaso, acentuó el descrédito del gobierno. Por otra parte, las organizaciones populares de oposición temían perder la iniciativa política conquistada y se negaron a participar.

El Foro que debía fomentar la participación ciudadana se inició en un clima de violencia: en esos días, las FPL asesinaron al Ministro de Educación, las organizaciones populares ocuparon varias embajadas y el gobierno impuso el estado de sitio implantando tribunales militares para juzgar acciones "contra la seguridad del estado'. Los representantes del Colegio Médico se retiraron del Foro 'por no encontrar un ambiente propicio a la libertad'. La ruptura de una institucionalidad ya de por sí cuestionada se dejaba entrever en el horizonte político.

Como respuesta al Foro Nacional, las organizaciones de oposición promovieron el Foro Popular, en setiembre de 1979, pocas semanas antes del golpe de estado del 15 de octubre. Este Foro contó con la participación de todas las organizaciones populares: el Partido Demócrata Cristiano (PDC), la Unión Democrática Nacionalista (UDN) y el Movimiento Nacional Revolucionario (MNR), todos ellos de oposición al gobierno, aunque en diversa medida. Este Foro concluyó con propuestas que iban al encuentro de las necesidades de las mayorías: cese de la represión, disolución de las instituciones represivas como 
ORDEN y UGB, libertad de organización y de expresión, mejoras salariales y acceso de los campesinos al uso de la tierra: una verdadera reforma del estado. Las propuestas del Foro Popular tenían el consenso de las cada vez más numerosas organizaciones populares, incluían la terminación de la represión contra los militantes de los movimientos populares, la disolución de las organizaciones terroristas de derecha, libertad real para las prácticas democráticas, medidas económicas que fueran el encuentro de las necesidades de las clases menos favorecidas, reconocimiento de las organizaciones populares y de su derecho a la participación en los espacios de decisión y medidas tendientes a garantizar el acceso a la tierra por parte de los campesinos. ${ }^{21}$ Estas medidas se vieron después plasmadas en la proclama de la Junta e Gobierno surgida del golpe de estado de octubre de 1979.

La militancia en las organizaciones populares o en la guerrilla se transformó en una opción válida para quienes miraban críticamente el desarrollo de los procesos sociales. Los estudiantes, los trabajadores urbanos y los campesinos, militantes de las organizaciones populares transformaron las manifestaciones y reclamos en cuestiones cotidianas y multitudinarias. ${ }^{22} \mathrm{El}$ gobierno perdió toda iniciativa, la oligarquía miraba con un temor creciente los sucesos y el ejército buscaba tímidamente una renovación que no alcanzaba nunca a concretar. Mientras, la Iglesia católica aceleraba su proceso de renovación que la llevaría a las divisiones internas más profundas de su historia.

\section{Monseñor Romero y la Democracia Cristiana}

Los demócratas cristianos de los primeros tiempos, y en este proceso es necesario incluir el Partido Demócrata Cristiano de El Salvador, han buscado llevar a la práctica los principios cristianos aplicándolos a la realidad del país: se trataba de adaptar estos principios al contexto regional. ${ }^{23}$

21. “...no más represión, disolución de la Organización Democrática Nacionalista (ORDEN), Fuerzas Armadas de Liberación Anticomunista y Guerra de Exterminio (FALANGE), Unión Guerrera Blanca (UDB), Mano Blanca, amnistía general, libertad a los reos políticos, participación política incluyente y pluralismo ideológico, libertad real de organización, reconocimiento del derecho de huelga, medidas económicas de corto plazo para detener la inflación, mejora de salarios, control de precios de artículos de consumo popular, control de alquileres, medidas económicas de largo plazo que garanticen de los campesinos a la propiedad y al uso de la tierra, instauración de un régimen democrático antes de las elecciones, participación efectiva de las organizaciones populares para garantizar un proceso de democracia real y la consolidación de un nuevo régimen político...". Citado por Baloyra, Enrique, El Salvador en transición, UCA Editores, $3^{\circ}$ edición, San Salvador pág. 123.

22. “...teníamos la impresión de ser arrastrados por una gran ola de la historia, actuando cada quien según sus propias motivaciones pero contribuyendo en conjunto a generar una especie de tragedia griega colectiva, donde la dirección de los acontecimientos era dada por fuerzas muy superiores a cualquier individuo." Román Mayorga, Una propuesta de paz al comienzo de la guerra, en Escobar Galindo, D. et. al., op.cit., pág. 10.

23. "La democracia cristiana no es una teoría abstracta e inflexible. Por el contrario, auténtica doctrina de realidades profundas, es capaz de asumir la orientación de diversas situaciones. Su tarea concreta varía de Continente a Continente, y deben variar sus tareas relativas a los instrumentos para conseguir, en una sociedad concreta, la promoción del hombre en la libertad y la justicia." Lino Rodríguez Arias, La democracia cristiana y América Latina. Testimonios de una posición revolucionaria, Editorial Universitaria, Lima, 1961, pág. 9 
En este intento, quedaba en juego la fidelidad a las ideas originarias. El Partido Demócrata Cristiano de El Salvador buscó adecuar estas ideas que dieron origen al Partido a la realidad que les hacía de entorno, tratando de que esta adecuación no signifique un abandono de las ideas originarias. ${ }^{24}$

La apertura de los años 60 había creado las condiciones para el diálogo entre los distintos sectores de la oposición y su fortalecimiento paulatino, lo que llevó por primera vez en la historia del país, a la presentación de un solo grupo político opositor en las elecciones presidenciales de 1972. Esta oposición representaba la exteriorización de la voluntad de amplios sectores sociales de la necesidad de un cambio político que contemplase las necesidades de las mayorías.

La posible apertura democrática originó un debate arduo en el seno de los distintos sectores del ejército $y$, en general, en los sectores cercanos a los gobiernos de turno. En el ejército, una tendencia más cercana a las reformas paulatinas que atendiesen las necesidades de las mayorías y fuese capaz de dialogar con la oposición, despertó el rechazo de la oligarquía. Esta tendencia se enfrentó con un sector partidario de hacer frente a la efervescencia popular por medio de la radicalización de la represión. El general José Alberto Medrano representaba a estos últimos, mientras que el coronel Arturo Armando Molina a los primeros. Por primera vez en su historia, las fuerzas armadas reflejaban un profundo debate interno que se traslucía hacia afuera de la institución. La intervención del presidente saliente, general Fidel Sánchez Hernández, que ostentaba el prestigio que le brindaba la corriente de nacionalismo exacerbado por la guerra con Honduras, definió la cuestión a favor del coronel Molina. La oligarquía se mostró recelosa ante esta situación.

Se presentaba así una oportunidad única para los distintos sectores de la oposición, en la cual se encontraban, cada vez más, los partidos políticos: enfrentar al poderoso aparato estatal en un escenario electoral, donde ya se entreveían posibilidades de ganar las elecciones. La oposición se concretó en la Unión Nacional Opositora (UNO), conformada por partidos políticos estructurados y movimientos de masas, donde confluía una gran diversidad de tendencias políticas que abarcaban un espectro político importante. Estaba conformada por dos movimientos de masas, el Movimiento Nacional Revolucionario (MNR) y la Unión Democrática Nacionalista (UDN); y por dos partidos políticos con una estructura partidaria afianzada. Por un lado, el Partido Comunista Salvadoreño (PCS), que había apoyado al gobierno militar en la guerra contra Honduras, y que había visto salir de sus filas las tendencias que propugnaban la lucha armada como único medio para la toma del poder político que llevaría a la revolución social. Por otro, el Partido Demócrata Cristiano (PDC), una vez

24. Muchos años después, un antiguo militante demócrata cristiano salvadoreño se expresaba en estos términos: “Nosotros, la Democracia Cristiana, queríamos una revolución en libertad; la izquierda quería una revolución armada... queríamos un país democrático y no un país autoritario". Entrevista con el Dr. Antonio Morales Ehrlich, antiguo militante de la Democracia Cristiana en El Salvador, en la sede del Partido Cambio Democrático, el 06.11.2013. Morales Ehrlich se refería a las opciones del partido Demócrata Cristiano al ser cuestionado acerca de la llegada a la Junta Revolucionaria de Gobierno surgida del golpe de estado del 15.10.1979. 
vencida la oposición interna de los grupos conservadores ligados a Napoleón Duarte, reacios a una alianza con el Partido Comunista. Pesaban siempre en el horizonte político las experiencias de Cuba y del Chile de Salvador Allende.

Por primera vez en su historia el Partido Demócrata Cristiano salvadoreño afrontaba una instancia democrática en alianza con otros grupos políticos.

En 1972 se enfrentaron la UNO y el oficialista Partido de Conciliación Nacional (PCN), y por primera vez el resultado resultaba incierto. La oposición se presentaba como una fuerza unificada por primera vez, donde confluían una gran diversidad de tendencias y modos de concebir la cuestión política. El oficialismo, por su parte, contaba con todo el aparato estatal y la presión de la oligarquía, que veía peligrar quizá por primera vez el sistema que protegía sus intereses. El temor oficial se concretó en amenazas, intimidaciones, atentados y agudización de la represión: urnas de plástico transparente, control de las elecciones por parte del ejército y una agresiva campaña en la prensa escrita fueron algunas de las formas de intimidación.

Las elecciones fueron ganadas claramente por la UNO pero el estado llevó a cabo un fraude clamoroso. ${ }^{25}$ Hubo protestas generalizadas por parte de los movimientos populares. Un intento de golpe de estado por parte de un sector 'demócrata y joven' de oficiales del ejército no encontró apoyo popular y fue abortado. La reacción de las fuerzas armadas se verificó en un aumento de la represión.

Uno de los protagonistas de esos tiempos calificó el fraude como 'fraude burdo y masivo' que debía evitar el fin de la dictadura militar, acelerando un proceso que desembocaría en la cruenta guerra civil. ${ }^{26}$

El fraude electoral de 1972 provocó un gran desengaño entre quienes todavía

\footnotetext{
25. "El fraude electoral de 1972 fue clamoroso. Y marcó un cambio definitivo en la vida política de nuestro país. Porque aquel año, frente al POCN, el eterno partido de los militares, se presentó la UNO, una alianza nueva, con los democristianos del PDC, los socialdemócratas del MNR y los comunistas de la UDN. Esta UNO de planteó una situación nueva a la oligarquía y a los militares La gente agarró la señal y votó masivamente por esta coalición para que cambiaran las cosas. Pero todo fue en vano. Los verdaderos ganadores de estas elecciones, Duarte y Ungo, protestaron ante todas las instituciones pero como siempre, al final, 'ganaron' los militares. Un fraude burdo, feo. Gobernaría el coronel Molina". Testimonio de Miguel Ventura, recogido por María López Vigil, Monseñor Romero. Piezas para un retrato, UCA Editores, San Salvador, 2011, pág. 41-42.

26. “...comenzó el 20 de enero de 1972, cuando los militares salvadoreños y sus aliados civiles hicieron un fraude burdo y masivo en las elecciones presidenciales de ese año. Mediante ese fraude le robaron las elecciones a dos civiles moderados, Napoleón Duarte y Guillermo Ungo, candidatos a presidente y vicepresidente de la República por la Unión Nacional Opositora (UNO), para evitar que terminara 'el gorilato', como llamábamos a una dictadura presidida por oficiales del ejército que se extendió por 48 años consecutivos desde 1931. El período de gestación desembocó en la guerra civil salvadoreña el 24 de marzo de 1980, fecha de un magnicidio (de Monseñor Oscar Arnulfo Romero, Arzobispo de San Salvador) que fue un parteaguas en la actitud de muchas personas, y la gota que derramó el vaso de la rabia acumulada en mucho tiempo. Ocho años de gestación, que unidos a los doce de la guerra propiamente dicha, sumieron al país en una honda crisis durante 20 años; es decir, de 1972 a 1992." Mayorga, R., op.cit., pág. 9.
} 
creían en los espacios de participación que ofrecía el sistema, y un profundo desencanto en quienes dirigían los procesos políticos de oposición. ${ }^{27}$

El año 1972 representó, asimismo, para el régimen, una oportunidad perdida para incorporar a su proyecto de país al bloque opositor, con el cual todavía se podía dialogar, legitimando así un sistema en el cual estaban claros los intereses y los privilegios, y en el cual se podían dar procesos de reformas que fueran, al menos aparentemente, al encuentro de las necesidades de las mayorías y que alejasen la posibilidad de un cambio repentino y violento.

Los partidos políticos comenzaron un largo periodo de generalizado descrédito ante la opinión de las clases marinadas y ante las clases que ostentaban los privilegios en El Salvador. Su falta de respuesta a las necesidades del país, y su creciente inoperancia política fueron dejándolos fuera del espectro político. La Democracia Cristiana conservaba solamente el antiguo prestigio que su trayectoria internacional le había legado. Las organizaciones populares, tanto las que habían elegido la vía armada como las que habían elegido la militancia opositora tomaron el lugar de los partidos políticos, y con ello, su iniciativa, su capacidad propositiva y su protagonismo. El nuevo fraude electoral de 1977 se dio en este contexto.

Hacia mediados de la década de los años 70, la militancia de las organizaciones populares había desbordado el papel de los partidos políticos. Éstos, que desde principios de la década se habían acostumbrado a mirar desde lejos cómo el ejercicio fraudulento de los procesos democráticos les había quitado todo protagonismo, estaban sumidos en un generalizado descrédito ante las clases marginadas.

En plena efervescencia nacional, y en medio de una aguda crisis política y social, se dio el golpe de estado de octubre de 1979. La Democracia Cristiana vio cómo sus banderas: reforma agraria y participación popular, se proponían ahora desde otros sectores: las fuerzas armadas protagonistas del golpe las proponían ahora desde el poder recientemente conquistado.

Los partidos políticos habían sido relegados a un segundo plano por su inoperancia, por enorme distancia con las mayorías marginadas, por su complacencia con un sistema que marginaba a las mayorías y por su aceptación de maniobras fraudulentas en una democracia corrupta. Su lugar fue ocupado por los movimientos populares, que tuvieron un enorme protagonismo en los años anteriores al golpe: identificaron las necesidades de las mayorías marginadas, ocuparon el 'peligroso lugar' de la oposición de un régimen represor y crearon

27. En palabras de uno de los protagonistas, Guillermo M. Ungo, "tratamos año tras año, década tras década, todas las vías posibles; participamos en numerosos eventos electorales, y el resultado fue siempre el mismo: fraude crecientes con represión y persecución política, restringiendo más y más el poco espacio democrático conquistado". Citado por Roberto Turcios, Una vida por la democracia y la paz, en Escobar Galindo, D. et.al., El Salvador, de la guerra civil a la paz negociada, Dirección de Cultura del Ministerio de Relaciones Exteriores, San Salvador, 2011, pág. 14. 
los espacios para la organización popular. El golpe de octubre de 1979 no hubiese sido posible sin la participación de los movimientos populares. ${ }^{28}$

La radio del arzobispado presentaba con agudeza en 1979, antes del golpe de estado de octubre, cuatro razones para el descrédito en el que caían los partidos políticos: la ausencia de militancia por parte de sus dirigentes - 'la poca fe y el escaso sacrificio'-, distanciados de las mayorías marginadas; la falta de conocimiento de la realidad nacional, que los ponía en situación de proponer soluciones a necesidades que ignoraban porque nunca habían estado en contacto con ellas; y la falta de fe en las posibilidades de las clases campesinas y obreras y en el poder de sus organizaciones; y, finalmente, el desprestigio de los partidos políticos propiciado por gobiernos que hacían hincapié en la seguridad nacional a costa de una represión sin límites. ${ }^{29}$

Sin embargo, la férrea oposición a las reformas por parte de la oligarquía, y la autonomía que conservaron las fuerzas armadas obligaron a imponerlas con la violencia: 'de nada sirven las reformas si van teñidas con tanta sangre', diría Monseñor Romero el 23 de marzo de 1980, un día antes de su asesinato.

El fracaso de la primera Junta Revolucionaria de Gobierno se hizo evidente el 4 de enero de 1980, cuando renunciaron los miembros civiles de la Junta y del gabinete: se habían 'agotado las posibilidades históricas de implementar en el país una salida democrática y pacífica...'. Para muchos, especialmente para las organizaciones radicales de la oposición, no quedaba otra salida que la vía armada.

La renuncia de quienes defendían los intentos reformistas de la Junta significaba el abandono de las soluciones intermedias: la Junta dejaba al descubierto su

28. "Las organizaciones populares llegaron a la convicción de que eran el imperialismo norteamericano, la burguesía criolla y la tiranía militar los causantes últimos de la injusticia institucional y de la represión. Y llegaron a la convicción de que sólo el pueblo organizado como alianza obrero-campesina, podía sacar a este país de su estado de postración, opresión y represión." El Salvador entre el terror y la esperanza. Los sucesos de 1979 y su impacto en el drama salvadoreño de los años siguientes, Compilado por Rodolfo R. Campos, UCA Editores, San Salvador, 1982, pág. 613. En su Tercera Carta Pastoral, de agosto de 1978, Monseñor Romero había defendido el derecho del pueblo a la organización.

29. "En el descrédito de los partidos políticos pueden verse varias causas. Una de ellas es la poca fe y el poco sacrificio de sus dirigentes; muchos de los dirigentes de los partidos políticos necesitan llevar un alto nivel de vida, para cuyo sostenimiento necesitan un trabajo remunerado que les ocupa la mayor parte de su tiempo hábil; en estas condiciones dedican al partido un tiempo residual, casi burocrático, sin cultivo apenas de las bases populares, excepto en tiempos de elecciones. Otra de las causas de su descrédito es vivir realmente de espaldas a las exigencias de las clases populares, con las que apenas mantienen contacto, pues no creen realmente en las virtualidades políticas de obreros y campesinos. Pero otra de las causas es la política seguida por los gobiernos de seguridad nacional, que han hecho lo posible, en la teoría y en la práctica, para desprestigiar a los partidos; no olvidemos que el desprestigio sistemático de los partidos es una de las consignas fundamentales de los gobiernos y de los intelectuales fascistas." El Salvador entre el terror y la esperanza. Los sucesos de 1979 y su impacto en el drama salvadoreño de los años siguientes, Compilado por Rodolfo R. Campos, UCA Editores, San Salvador, 1982, pág. 226-227, programa del 28 de abril de 1979. 
incapacidad para ir al encuentro de los reclamos de las organizaciones populares y para abrir espacios de diálogo y de participación. La oposición recuperaba así la iniciativa.

Sin embargo, tanto la embajada de Estados Unidos como los militares que habían provocado el golpe hicieron un intento de salvar el proceso: invitaron al único partido político que conservaba algún resabio de prestigio a participar en el proceso iniciado. Y el lugar que dejaban vacante en el gobierno los partidarios de las reformas fue ocupado por la Democracia Cristiana para entrar a formar parte del poder político.

Para ello debió aliarse con las fuerzas que quedaban: las fuerzas armadas. Éstas, fuertemente cuestionadas por la dinámica que adquiría un golpe de estado que había cambiado las cosas para que todo siga igual, se vio obligada a confirmar su decisión de llevar adelante las reformas necesarias tendientes a 'producir el cambio de la estructura de poder económico social y político del país, para pasar de una estructura oligárquica... a una sociedad de amplia participación' ${ }^{30}$

Paradójicamente, las fuerzas armadas debían ahora llevar a cabo, desde el gobierno, los reclamos que el Foro Popular había propuesto meses antes, y que eran, precisamente, los reclamos de la oposición. Para ello, buscaron el acompañamiento de una Democracia Cristiana profundamente cuestionada. ${ }^{31}$

El evidente descontrol de la situación de violencia por parte de la Junta de Gobierno motivó que el 10 de enero de 1980, de un pacto entre la Fuerza Armada y el Partido Demócrata Cristiano, surgiera la Segunda Junta de Gobierno, partiendo de la renuncia de los elementos civiles de la primera junta. Con todo, los viejos problemas sociales continuaron, añadiéndose a éstos otros nuevos: los refugiados y los desplazados de la guerra interna, cada vez más intensa. Muchos campesinos huyeron de las regiones rurales del terror causado por las incursiones del ejército, buscando refugio en las ciudades y en los países vecinos, especialmente en Honduras.

El papel de la Democracia Cristiana en la Junta de Gobierno fue muy criticado por diversos sectores de la oposición. Junto al asentimiento de la embajada de Estados Unidos, que veía que su intervención podía generar consensos, las organizaciones populares, las organizaciones armadas de la guerrilla y los sectores de la Iglesia católica que seguían al arzobispo Romero encontraron elementos para el cuestionamiento. El arzobispo criticaba la presencia de la Democracia Cristiana en el gobierno, ya que encubría a nivel internacional la represión del régimen". ${ }^{32}$

30. 'La fuerza armada al pueblo salvadoreño', San Salvador, 9 de enero de 1980, reproducido por Mariano Castro Morán, op.cit., anexo número 15, pág. 416-419.

31. Gordon, Sara op.cit., pág. 315 y ss.

32. "A la Democracia cristiana le pido que analice no sólo sus intenciones, que sin duda pueden ser muy buenas, sino los efectos reales que su presencia en el gobierno está ocasionando. Su presencia está encubriendo, sobre todo a nivel internacional, el carácter represivo del régimen actual. Es 
El costo político para el Partido Demócrata Cristiano por el apoyo a la Junta de Gobierno fue grande, y contribuyó al alejamiento definitivo de este partido de las organizaciones populares, lo que repercutiría en las décadas siguientes.

Y en abril de 1979, el Partido Demócrata Cristiano de El Salvador emitía un comunicado destacando el crecimiento de las fuerzas populares, especialmente las organizaciones urbanas. Sin embargo, no se vieron cambios en la dirigencia ni en las políticas partidarias que demuestren también una decidida intención partidaria de realizar un trabajo organizativo y reivindicativo, con propuestas que vayan verdaderamente al encuentro de las necesidades de las mayorías marginadas: sus dirigentes no las habían padecido. Por otra parte, el Partido estaba acostumbrado a acuerdos tácitos con el gobierno, que contemplaban la anuencia a procesos fraudulentos que hacían posible su existencia en un régimen represor. La ausencia de una decidida opción por una política de denuncia de las irregularidades de los gobiernos de turno, y de un análisis profundo de la empresa 'privada en el país, le la escasa restaba credibilidad que ostentaba.

En ese sentido, la Democracia Cristiana había recuperado algo de su perdida credibilidad en un segundo comunicado de julio de ese mismo año 1979, en respuesta a la propuesta del presidente Romero de abrir un diálogo nacional, el 'Foro Nacional'. El comunicado exigía la apertura de un 'auténtico proceso de democratización' que haga posible la práctica de los derechos y el cese de la represión. Este comunicado implicaba el intento de salir de su inmovilismo por parte del Partido, para ir al encuentro de los problemas reales: las violaciones de los derechos humanos, la represión ilegal, las prácticas fraudulentas, el autoritarismo del gobierno. La decisión de participar en el Diálogo Nacional venía condicionada por la exigencia de posibilidades reales de un diálogo abierto y sin exclusiones que haga posible la paulatina democratización de los aparatos estatales y de respeto a los derechos. El arzobispado de San Salvador se pronunciaba favorablemente ante este comunicado. ${ }^{33}$

Este condicionamiento se repetía poco después, ante la proximidad de elecciones para alcaldes y diputados. Uno de sus dirigentes históricos, Antonio Morales

urgente que como fuerza política de nuestro pueblo vean desde dónde es más eficaz utilizar esa fuerza en favor de nuestros pobres. Si aislados e impotentes en un gobierno hegemonizado por militares represivos o como una fuerza más que se incorpora a un amplio proyecto del gobierno popular, cuya base de sustentación no son las actuales fuerzas armadas, cada vez más corrompidas, sino el consenso mayoritario de nuestro pueblo". Homilía en la misa del 17.02.80, citado por María López Vigil, Monseñor Romero, Piezas... pág. 340.

33. "...De ahí la importancia de señalar el compromiso de la democracia cristiana de exigir, antes de participar en foros y reuniones, la urgencia de democratizar la vida nacional, en un inicio esperanzador de que el proceso conflictivo y violento que padecemos, se racionalice, se reacomode históricamente con la confluencia de sectores ahora marginados y excluidos de las decisiones politicas.

El tomo del manifiesto nos parece apropiado para dialogar...". Citado por El Salvador entre el terror y la esperanza. Los sucesos de 1979 y su impacto en el drama salvadoreño de los años siguientes, Compilado por Rodolfo R. Campos, UCA Editores, San Salvador, 1982, pág. 373-374, programa del 30 de julio de 1979. 
Ehrlich, exigía 'signos de credibilidad' al gobierno ante las próximas elecciones: un ambiente de libertad de expresión política donde sea posible el proselitismo partidario sin represión y la posibilidad de expresarse y de proponer cambios. ${ }^{34}$

La Democracia Cristiana abandonó rápidamente el Foro Nacional por no reunir las condiciones que exigía, demostrando así la escasa consideración que el gobierno tenía de ella como posible aliado político. El partido se integró al Foro Popular propuesto por las organizaciones populares. El gobierno surgido del golpe de estado de octubre volvería a mirar a la Democracia Cristiana para darle visos de legalidad a su gobierno, pero ya el contexto social y político sería otro.

Monseñor Romero comentaba en forma positiva estas exigencias de la Democracia Cristiana, pero exigía coherencia de sus comunicados con su accionar político: ante el asesinato del sacerdote Alirio Napoleón Macías, párroco de San Esteban Catarina, el 4 de agosto de 1979, el arzobispo exigía 'signos de credibilidad' al gobierno, aclarando el hecho y castigando a los culpables; y a la Democracia Cristiana, que había condicionado su participación en las elecciones próximas a un ambiente de libertad y al cese de la represión, a ser coherente con su condicionamiento. ${ }^{35}$

El arzobispo, por su parte, condicionaba su apoyo al proceso político a la aclaración del asesinato, poniendo en juego el inmenso ascendiente que la Iglesia católica tenía sobre las grandes mayorías populares. ${ }^{36}$ A fines de 1979 , Romero comenzaba ya la radicalización de sus opciones, que haría explícitas claramente en los tres primeros meses de 1980, desde enero hasta su asesinato en marzo.

34. “...la democracia cristiana ha pedido una señal de sus buenas intenciones al gobierno; de otra manera, dicen, no hay participación y no hay elecciones que valgan”. El Salvador entre el terror y la esperanza. Los sucesos de 1979 y su impacto en el drama salvadoreño de los años siguientes, Compilado por Rodolfo R. Campos, UCA Editores, San Salvador, 1982, pág. 384, programa del 7 de agosto de 1979.

35. "Esta es una ocasión para que la democracia cristiana exija este signo de credibilidad al gobierno: que se delimiten responsabilidades y que se castigue a los culpables. Y si no se hace nada de esto, como ha sido habitual en casos parecidos, entonces ahí tienen el signo: un signo de que los gobernantes no tienen, por más que lo digan en público, intenciones verdaderas de cambiar nada; que las promesas son ya falsas y mendaces o, lo que es bien grave, que no disponen del poder coercitivo suficiente para hacer cumplir a los subordinados las promesas de los jefes. La democracia debe, por su bien y por su futuro, exigir este signo y poner todo su poder de negociación en juego, para que se acabe la persecución a la Iglesia y al pueblo...". El Salvador entre el terror y la esperanza. Los sucesos de 1979 y su impacto en el drama salvadoreño de los años siguientes, Compilado por Rodolfo R. Campos, UCA Editores, San Salvador, 1982, pág. 384, programa del 7 de agosto de 1979.

36. “... que no se hagan ilusiones: la Iglesia Católica, no la iglesia de los falsos pastores y de los mercenarios, sino la Iglesia que mueve masas y mucho más corazones, no se prestará al juego electoral. $Y$ hablando en términos políticos, tanto la democracia cristiana como el gobierno saben muy bien que si la Iglesia Católica de El Salvador da a sus millones de fieles la consigna de abstenerse de este nuevo engendro electoral, la abstención será muy elevada y la maniobra un nuevo fracaso político. Si quieren elecciones, hagan antes justicia." El Salvador entre el terror y la esperanza. Los sucesos de 1979 y su impacto en el drama salvadoreño de los años siguientes, Compilado por Rodolfo R. Campos, UCA Editores, San Salvador, 1982, pág. 384-385, programa del 7 de agosto de 1979. 


\section{La efervescencia social y política: el Foro Popular}

Los años finales de la década de los 70 en El Salvador fueron los tiempos de mayor efervescencia popular: los tiempos de las grandes manifestaciones y de huelgas masivas con gran aceptación popular. ${ }^{37}$ Fueron, también, los tiempos de la represión selectiva, dirigida contra los dirigentes de las organizaciones populares y los sacerdotes de las comunidades eclesiales de base: se asesinaba a los sacerdotes Rafael Palacios y Alirio Macías, se cometían atropellos contra los dirigentes de las organizaciones populares, se atentaba contra los medios de comunicación del arzobispado y de la oposición, se incentivaba la propaganda contra Monseñor Romero y los jesuitas, aumentaba el número de 'desaparecidos'.

Hacia fines de la década de los años 70 en El Salvador la historia 'se aceleraba' y el tiempo de la revolución parecía inminente. El gobierno del presidente Romero buscó ampliar su base de aceptación levantando el estado de sitio, aumentando los sueldos de los empleados públicos y autorizando el regreso de los refugiados políticos. Al mismo tiempo, anunciaba cambios económicos y amenazaba con 'neutralizar todo foco de perturbaciones que amenacen desestabilizar nuestras instituciones republicanas...'..$^{38}$

Las fuerzas armadas, por su parte, por primera vez en su historia iniciaban un amplio debate interno. Un sector conservador, ligado a viejos esquemas, propiciaba la eliminación física de toda oposición, coincidiendo con el sector más radical de la oligarquía. Un sector moderado, formado por oficiales formados en Estados Unidos y defensores de la Doctrina de la Seguridad Nacional, preconizaba reformas parciales controladas verticalmente y la represión con dureza de los movimientos reivindicativos y las agrupaciones populares ilegales independientes; sus integrantes provenían de la Guardia Nacional y coincidían con el sector 'modernizante' de la oligarquía. Por último, un sector 'constitucionalista', formado en México, compuesto por oficiales jóvenes descontentos con los métodos utilizados para la represión, buscaba aplicar reformas que atendiesen a los reclamos de la oposición.

La política estadounidense, siempre presente, miraba con escepticismo la capacidad del gobierno del general Romero para abrir consensos y para ir al encuentro de las necesidades de las mayorías aceptando 'el disentimiento y

37. "San Salvador era una ciudad donde se respiraba la conspiración. Estábamos a principios de 1980. Todos los días habían (sic) marchas y tomas de ministerios. Habían gigantescas organizaciones de masas, el Bloque Popular Revolucionario, el FAPU, las Ligas Populares 28 de Febrero, existía la Coordinadora Revolucionaria de Masas. Todo mundo (sic) estaba organizado en una de las cinco organizaciones político-militares o era simpatizante. Mucha gente andaba armada.

Se utilizaban pseudónimos. San Salvador era un hervidero de rebeldía. Había un entusiasmo, una confianza, la convicción que la huelga general y la insurrección iban a hacer colapsar a la dictadura militar. A partir del asesinato de Monseñor Romero en marzo del 80 todo esto se modifica y se crean las condiciones para una lucha larga, que duró doce años y que se desarrolló fundamentalmente en las zonas rurales, en Morazán y Chalatenango." Rafael Menjívar Ochoa, Tiempos de locura: El Salvador 1979-1981, Índole Editores-FLACSO El Salvador, San Salvador, 5ª ed., 2008, pág. 127.

38. La Prensa Gráfica, Discurso del presidente Carlos Humberto Romero del 16.08.1979, 17.08.1979, pág. 1-2. 
las demandas de cambio' para calmar la efervescencia popular que podría derivar en revoluciones al estilo de la vecina Nicaragua. Al principio, alentaron las reformas, pero, al advertir que el gobierno no controlaba la efervescencia social, buscaron un cese anticipado del proceso político, adelantando la salida del presidente. En ese intento, buscaron en el 'sector constitucionalista' del ejército quien pudiese llevar a cabo ese paso, desalentando a los conservadores partidarios de medidas represivas radicales. El golpe de octubre de 1979 fue, en gran medida, propiciado por Estados Unidos. ${ }^{39}$

Se hablaba más arriba del 'quiebre' que significaba el golpe de estado de octubre de 1979, que podría asemejarse a los ‘quiebres’ de los años 1932 o 1972 , como uno de los momentos más importantes de la historia salvadoreña del siglo XX. ${ }^{40}$ Es necesario volver unos años atrás para aclarar algunas circunstancias del golpe de estado del 15 de octubre de 1979 y las reacciones de Monseñor Romero. En 1977, poco después de su llegada al arzobispado de San Salvador, asumió la presidencia del país el general Carlos Humberto Romero. Éste, ante la efervescencia general y el descontento generalizado y público para con un gobierno surgido de elecciones fraudulentas y con la aquiescencia de la oligarquía y los sectores militares tradicionales, no supo ver la oportunidad que se abría para tomar la iniciativa de un diálogo abierto y sincero, que ofreciese espacios para la participación sin marginaciones. Prefirió mantener la vieja alianza de los militares con los intereses de la oligarquía. Su gobierno, basado en el 'Plan Bienestar para Todos', favoreció la sanción de la Ley para la Defensa y Garantía del Orden Público, que daba rienda libre a las fuerzas controladas por el estado para llevar a cabo la represión contra las organizaciones populares. Aumentaron, así, las violaciones a los derechos de las personas, el accionar de los 'escuadrones de la muerte' y de ORDEN.

Ello provocó la respuesta de las organizaciones de campesinos, estudiantes y obreros: hubo tomas de tierras para exigir el derecho a poseer la tierra que se trabajaba; y de fábricas, como la cervecera La Constancia, para exigir aumento de salarios; y manifestaciones de los pobladores de los tugurios, para exigir terrenos para la construcción de viviendas y tomas de embajadas. ${ }^{41}$ Asimismo, provocaron manifestaciones los estudiantes, los comerciantes callejeros y las mujeres. Todo esto llevó a un creciente clima de efervescencia popular y de inestabilidad política. En estas circunstancias, el arzobispo Romero había optado por tomar partido por la defensa de los derechos de las personas, denunciando

\footnotetext{
39. Gordon, Sara, op.cit., pág. 268-282.

40. Según uno de sus protagonistas, "Ocurrió cuando era imposible no solo negar la crisis del modelo instaurado en 1932... sino también cuando el país se veía ante una encrucijada fatal, precisamente, a partir de dicha crisis: el estallido de una guerra civil de consecuencias que solo ahora podemos medir o el intento de instaurar un modelo democrático inédito en el país...". Guerra y Guerra, R., Un golpe al amanecer. La verdadera historia de la proclama del 15 de octubre de 1979, Índole Editores, San Salvador, 2009, pág. 14.

41. El 5 de mayo de 1979, por ejemplo, miembros del Bloque Popular Revolucionario (BPR) toman las embajadas de Costa Rica, Francia y Venezuela y la catedral de San Salvador. Las fuerzas armadas reprimieron a los manifestantes en las afueras de la catedral con un saldo de 15 muertos.
} 
públicamente los atropellos en sus discursos, en sus homilías en las misas y en sus entrevistas con medios de prensa. ${ }^{42}$

La llegada al poder político por parte del Frente Sandinista para la Liberación Nacional en la vecina Nicaragua, junto a la cercanía geográfica e ideológica de Cuba, ponía el conflicto en un horizonte mucho más amplio: el de la guerra fría. Ello incentivó la conformación de diversos grupos políticos de oposición y de organizaciones armadas, que ya comenzaban a salir a 'vida pública', presentando un nuevo elemento con el que había que contar desde entonces y cada vez más: la guerrilla.

Ante la crisis, el presidente Romero, cada vez más solo en el poder, buscó espacios de entendimiento y de apoyos. El 17 de mayo de 1979, cinco meses antes del golpe de estado, lanzó una propuesta de diálogo 'con honestidad, franqueza, sinceridad': el 'Foro Nacional'. Sería un diálogo abierto, al que estaban llamadas las organizaciones gremiales, políticas, sociales y religiosas. Buscaba ir al encuentro de los reclamos de las mayorías marginadas. En el fondo, buscaba permanecer en el poder seriamente amenazada por las crisis.

Esta propuesta despertó, en un primer momento, amplias expectativas, especialmente en el arzobispado de San Salvador ${ }^{43}$ y en los partidos políticos: el primero veía una solución posible a la crisis; los segundos, veían la posibilidad de recuperar un protagonismo que habían perdido.

Enseguida surgieron propuestas de todo tipo: necesidad de una 'amplia y total amnistía política', por parte del arzobispado; una participación irrestricta y sin condicionamientos previos, por parte de los partidos políticos; el cese de la represión, por parte de los movimientos populares: resultaba poco lógico continuar la represión contra quienes estaban participando en el diálogo propuesto por el gobierno.

La dividida Conferencia Episcopal de El Salvador fue invitada a participar del Foro Nacional, invitación que aceptó, mandando dos participantes. Sin embargo, el asesinato de Alirio Napoleón Macías, sacerdote de la diócesis de San Vicente, de la cual era obispo Monseñor Aparicio, el mismo que presidía la Conferencia Episcopal, provocó el retiro de los dos representantes: 'un poco

42. "Monseñor Romero apoya y defiende los derechos de los pobres, sus homilías en Catedral son reconocidas como la voz de los sin voz". Sobrino, Martín-Baró, Cardenal, op.cit., pág. 44.

43. "Podría empezar a construirse un proceso de participación política de las mayorías con vistas a hacer válido el principio de soberanía popular sobre el cual se erige todo el aparato jurídico de la república... Podría comenzarse a construir una patria, una nueva patria, donde poco a poco se destierren los métodos y sistemas de dominación y explotación de nuestras clases laborales, y se distribuyan los beneficios de la producción económica, se eleven las condiciones de vida material y espiritual del pueblo y se supriman los privilegios que vuelven dicotómica la sociedad, dividiéndola en los de arriba y los de abajo, en los que todo tienen y los que no tienen nada. Podría iniciarse así un proceso nuevo, dinámico, y vigoroso...". El Salvador entre el terror y la esperanza. Los sucesos de 1979 y su impacto en el drama salvadoreño de los años siguientes, Compilado por Rodolfo R. Campos, UCA Editores, San Salvador, 1982, pág. 262, programa del 18 de mayo de 1979. 
tarde, pero los ha sacado', comentaba la radios ISAX.

Meses antes, Monseñor Aparicio había advertido públicamente a los sacerdotes que apoyaban las organizaciones populares, porque 'tomaban caminos equivocados’, advertencia que incluía prácticamente una velada amenaza.

El arzobispado de San Salvador reaccionó favorablemente ante este retiro: luego de los primeros momentos de aceptación del diálogo que 'abría amplias expectativas', había pasado a una actitud de franco rechazo, cuando las condiciones del diálogo se vieron restringidas.

La reacción de la Conferencia Episcopal, aunque tardía y contradictoria, ya que se retiraba de un diálogo del cual poco antes había aceptado formar parte, era una advertencia al gobierno ante los asesinatos de sacerdotes, ${ }^{44}$ ponía en evidencia la inutilidad del Foro y la falta de representatividad real y de transparencia, y hacía evidente la falta de voluntad política para llevar adelante un diálogo que la represión cotidiana negaba constantemente.

Por su parte, los mensajes públicos del presidente Romero ponían en tela de juicio las intenciones invocadas en ocasión del llamado público al diálogo. Por un lado hablaba de la existencia de subversión, representada en el accionar de las organizaciones populares; por el otro, y de la falta de justicia social. ${ }^{45} \mathrm{En}$ el fondo, la postura aceptada por las dirigencias de las organizaciones populares era que no se podían hacer cambios verdaderos sin la presencia de la oposición y de quienes representaban a las grandes mayorías marginadas.

En la práctica, y luego de una convocatoria que contenía muchas marginaciones, los dialogantes que representaban al gobierno se quedaron con pocos interlocutores: los que representaban a la empresa privada y pocos más, representantes de sectores minoritarios.

Las medidas sociales y económicas que este Foro hizo llegar al gobierno como propuestas que debían dar salida a la crisis fueron devueltas por el Consejo de Ministros en setiembre de ese mismo año, con el comentario de que muchas de ellas 'son ya realidad' con las medidas tomadas por el gobierno: para el gobierno, la crisis sólo era cuestión de leves aumentos de salarios, construcción

44. Entre 1977 y 1980, los años del trabajo de Monseñor Romero en San Salvador, hubo seis sacerdotes asesinados.

45. "Su discurso (del Presidente Romero) contiene dos ideas principales: la primera, hay subversión, y por tanto la Fuerza Armada debe reprimirla; segunda, hay una gran injusticia social y por tanto la Fuerza Armada tiene que propiciar cambios sociales. Como subversión se llama a toda acción seria que se tome para concientizar y organizar al pueblo en defensa de sus intereses, la propuesta del Presidente Romero cae en flagrante contradicción. No se pueden hacer profundos cambios sociales sin la presencia y la presión del pueblo oprimido y explotado, y se impide la presencia y la presión de este pueblo reprimiéndolo, asesinándolo, acallándolo por todos los medios, sobre todo por medios ilegales, completamente al margen de la Constitución." El Salvador entre el terror y la esperanza. Los sucesos de 1979 y su impacto en el drama salvadoreño de los años siguientes, Compilado por Rodolfo R. Campos, UCA Editores, San Salvador, 1982, pág. 399, programa del 13 de agosto de 1979. 
de viviendas y de escuelas, dejando de lado el acceso a la tierra y a los espacios de decisión. ${ }^{46}$ La respuesta produjo el desencanto de las expectativas que había creado: 'demasiado poco y demasiado tarde': el Foro perdía rápidamente credibilidad e interlocutores, y la idea de que era necesario poner fin a la crisis por medios radicales ganaba adeptos en todas partes.

De este modo, las palabras del presidente Romero perdían credibilidad día a día: el fracaso del Foro Nacional conducía irremediablemente al fracaso de la gestión del presidente y hacía más fácil la 'agenda paralela' de las fuerzas armadas, cada vez más convencidas de la necesidad de un proceso que reprimiese los cuestionamientos al sistema. Los anuncios del presidente de elecciones libres en el año 1980, y la promesa de respetar el resultado de las urnas. ${ }^{47}$

Paralelamente, las organizaciones populares propusieron un 'Foro Popular', que, dejando de lado las restricciones, se abocó a un diálogo amplio, y en el mismo mes que el Consejo de Ministros del presidente Romero desestimaba a las propuestas del Foro Nacional, hacía pública las suyas en conferencia de prensa.

La representatividad del Foro Popular era innegable: participaron en él el Partido Demócrata Cristiano; las organizaciones populares, aquéllas de las cuales había hablado Monseñor Romero en su Tercera Carta Pastoral de agosto del año anterior: las Ligas Populares 28 de Febrero (LP-28), que luego se opondrían al golpe de estado de octubre, porque el golpe 'secuestraba' las banderas y los reclamos del Foro Popular; el Movimiento Nacional Revolucionario (MNR), la Unión Democrática Nacionalista (UDN); los sindicatos más representativos, como la Federación Nacional de Sindicatos de Trabajadores Salvadoreños (FENASTRAS), que sufriera un cruento atentado a sus instalaciones en ese mismo año. Faltaban, solamente, las organizaciones Bloque Popular Revolucionario (BLOQUE) y el Frente de Acción Popular Unificada (FAPU), aunque éste estaba representado en FENASTRAS.

El mismo hecho de que se llevase a cabo paralelamente al Foro Nacional era de por sí un mensaje provocador: las organizaciones populares prescindían del gobierno en un diálogo sobre la crisis nacional. En este camino, las soluciones podían dejarlo de lado y el poder político podía quedar marginado de los

46. “...Creer, por ejemplo, que con promesas, ya antes incumplidas, se van a calmar las insatisfacciones de los trabajadores agrícolas es no entender que la clase rural necesita con urgencia ser incorporada como sujeto histórico de producción, con todos los beneficios que la legislación moderna le otorga al que trabaja la tierra. Con razón se ha afirmado que la tierra debe ser del que la trabaja y no del rentista ausente o empresario que especula con los bienes y productos, sin atender las necesidades primordiales de los agentes de trabajo". El Salvador entre el terror y la esperanza. Los sucesos de 1979 y su impacto en el drama salvadoreño de los años siguientes, Compilado por Rodolfo R. Campos, UCA Editores, San Salvador, 1982, pág. 497-498, programa del 21 de setiembre de 1979.

47. "Esta vez sí se respetará el sufragio de las urnas y no habrá fraude ni coacción alguna...”. El Salvador entre el terror y la esperanza. Los sucesos de 1979 y su impacto en el drama salvadoreño de los años siguientes, Compilado por Rodolfo R. Campos, UCA Editores, San Salvador, 1982, pág. 409, programa del 17 de agosto de 1979. 
procesos que llevasen a una solución de la crisis que todos admitían.

Las propuestas de este Foro, partiendo de un diagnóstico de la realidad nacional, contenía propuestas y acuerdos mínimos: un verdadero paquete de medidas urgentes que contemplaban desde la reforma agraria, hasta la nacionalización de la banca y una mayor justicia en el reparto de la riqueza producida: un ataque al corazón de los privilegios de la oligarquía. Estas propuestas eran, además, públicas, lo que no sucedía con las del Foro Nacional. En general se constataba una certeza en la posibilidad de los procesos democráticos como salida a la crisis: una 'auténtica democratización del país y una auténtica participación popular en el destino político de la nación, en sus riquezas y en sus recursos' ${ }^{48}$

En este clima de efervescencia política y social, en agosto de 1979 Monseñor Romero hacía pública su Cuarta Carta Pastoral, que sería la última; y en octubre tenía lugar el golpe de estado de los oficiales jóvenes del ejército.

\section{La Cuarta Carta Pastoral de Romero}

Romero comenzó a dar muestras de la radicalización de sus opciones, siempre apegado a los documentos que en ese entonces producía la jerarquía de la Iglesia católica en el CELAM, ya desde la publicación de su Tercera Carta Pastoral, que escribe junto a Monseñor Rivera Damas, obispo de Santiago de María, y que ya tratamos en el Capítulo 3. Esta línea continúa en los años 1979 y 1980, y se manifiesta en forma cada vez más explícita.

Sus cuatro Cartas anteriores, incluyendo en esto la que escribió en 1975 desde Santiago de María, fueron posteriores al documento de Medellín de 1968; efectivamente, se nota la influencia de este documento. Esta quinta y última Carta es posterior al documento de Puebla, del CELAM, dado a conocer en enero de 1979: la Carta pastoral de Romero fue dada a conocer el 6 de agosto de 1979, y sería la última que escribiría. De hecho, en esta carta, a las citas del documento de Medellín se añaden las del documento de Puebla.

La Iglesia católica había cambiado desde la Tercera Carta Pastoral, en agosto de 1978. La mayor parte de los obispos se habían manifestado, ahora abiertamente, hostiles al trabajo de Romero. Algunos de ellos no abandonar sus privilegios que le otorgaba su aquiescencia a un sistema social con privilegiados y marginados. Otros, ignorando la 'profunda renovación que proponías los documentos del Vaticano II y de Medellín y Puebla, consideraban que la arquidiócesis había entrado en un proceso de ideologización. ${ }^{49}$

48. "Estamos absolutamente convencidos de que sólo la acción de las organizaciones populares es garantía de realización de un verdadero proceso de democratización". El Salvador entre el terror y la esperanza. Los sucesos de 1979 y su impacto en el drama salvadoreño de los años siguientes, Compilado por Rodolfo R. Campos, UCA Editores, San Salvador, 1982, pág. 495-496, programa del 21 de septiembre de 1979.

49. Luis Coto S. J., La Eclesiología en el pensamiento de Mons. Oscar A. Romero, ponencia en el II Simposio I Teológico sobre Monseñor Romero, Universidad Centroamericana José Simeón 
La primera parte de la Carta pone en evidencia la influencia del documento de Puebla y la fidelidad de Romero a este documento. En efecto, son tomados del documento de Puebla los argumentos que tratan sobre la represión, la injusticia social y el análisis de los sistemas económicos. Y añade un tema en esos momentos crucial para el arzobispo de San Salvador: la unidad de la Iglesia.

La segunda parte presenta una orientación doctrinal desde el punto de vista de un trabajo pastoral integral y liberador de las injusticias institucionalizadas. Y menciona las 'tres absolutizaciones': la absolutización de la propiedad privada y la riqueza, la de la seguridad nacional y la absolutización de la organización.

La tercera parte presenta un nuevo panorama de la violencia, ya tratado en su Tercera Carta Pastoral y ahora con algunas ideas tomadas del documento de Puebla. Al tiempo que rechaza distintas formas de violencia, admite la posibilidad de la violencia de la insurrección, tema en el que insistirá a mediados de octubre de ese año de 1979, en ocasión del golpe de estado de los 'militares jóvenes'.

Luego, aborda la discusión en torno al marxismo y el capitalismo, el diálogo nacional ${ }^{50}$, y termina presentando las propuestas de opción preferencial por los pobres y los jóvenes del documento de Puebla, y el trabajo pastoral de las comunidades eclesiales de base.

Esta Cuarta Carta Pastoral se publicó el 6 de agosto de 1979 y será la última que escribirá. Se titula Misión de la Iglesia en medio de la crisis que vive el país, y está dirigida, como las anteriores, a los religiosos y sacerdotes de la arquidiócesis de San Salvador y a los 'salvadoreños de buena voluntad'. Por primera vez, Romero numera los párrafos de sus Cartas, lo que facilita la citación.

El título mismo de la carta ya significa una postura: el país está en crisis: 'nuevas formas de sufrimientos y atropellos han empujado nuestra vida nacional por caminos de violencia, venganza y resentimiento'51, y la Iglesia está en medio de esa crisis.

Efectivamente, la Carta refleja una inmersión en la vida del país, de lo que resulta un análisis 'desde adentro'. La cercanía con las mayorías marginadas, con las asociaciones populares, y con numerosas personas de la dirigencia política y de las clases que detentaban el poder económico, le proporcionaban elementos para una visión profunda de la situación nacional.

Romero se pronuncia en esta Carta sobre la situación política del país, el Foro

Cañas, UCA, 31.03.2005, en http://www.uca.edu.sv/cmr/semana_teologia.htm, recuperado el 30.09.2014

50. Son los meses en los cuales el país se debatía entre el Foro Nacional propuesto por el presidente Carlos H. Romero, y el Foro Popular propuesto por las organizaciones populares.

51. Cuarta Carta Pastoral de Monseñor Romero, Misión de la Iglesia en medio de la crisis que vive el país, editada por el Arzobispado de San Salvador, 3, en http://www.romeroes.com/monsenorromero-su-pensamiento/cartas-pastorales, consultado el 24.09.14 
Nacional convocado por el presidente Carlos Humberto Romero, la situación económica, las organizaciones populares, la violencia, la situación de la Iglesia, la riqueza, la propiedad privada y las minorías privilegiadas, la injusticia social y las fuerzas armadas. Finalmente, se pronuncia sobre la misión de la Iglesia en esas circunstancias.

\section{- Sobre la situación política y el Foro Nacional}

Siguiendo la línea de análisis de las Cartas anteriores, y citando al documento de Puebla, Romero presenta una situación política deteriorada, en la que la injusticia social se ha institucionalizado provocando un grave deterior de las condiciones de vida. ${ }^{52}$

Esto queda en evidencia en la corrupción de las instituciones del estado, las que se han transformado en instrumentos de un sistema que perpetúa la marginación. En esta situación están, incluso, los organismos encargados de hacer cumplir las leyes. ${ }^{53}$

Para Romero, las desigualdades sociales, la pobreza y los atropellos a los derechos humanos ${ }^{54}$ conforman una situación de injusticia generalizada, cuyas consecuencias influyen en la marginalidad en la que viven que las mayorías. Nuevamente, se apoya en documentos formales, esta vez en la encíclica Populorum Progressio del papa Pablo VI, cuando hace alusión al concepto 'pasar de situaciones menos humanas a situaciones ${ }^{55}$ más humanas'. Y el numeral 13 de la Carta, para referirse a la situación del país, cita el reciente documento de Puebla, del CELAM, aludiendo al 'clamor sordo de miseria', que transformado en 'claro, creciente, impetuoso y, en ocasiones, amenazante'; poniendo en evidencia su clara percepción de la realidad, presentando las consecuencias concretas de esta situación: la mortalidad infantil, la falta de viviendas, los problemas de salud, los salarios de hambre, el desempleo, la desnutrición y la inestabilidad laboral.

La Carta presenta la urgente necesidad de poner remedio a esta situación de efervescencia social, el que deberá venir de un diálogo en el que participen todos los sectores sociales. Este cambio deberá cambiar las estructuras, en la que hay beneficiados y marginados. Sin embargo, el diálogo se hace difícil ante

52. Ídem, 14, citando el documento de Puebla, 46.

53. "La infidelidad de la Corte Suprema de Justicia y de las otras instancias de la administración de la justicia a su altísima misión de cumplir y hacer cumplir la Constitución de un país democrático, prestándose, en cambio, a ser débiles instrumentos al capricho de un régimen de fuerza". Ídem, 19. "Inseguridad total por detenciones sin órdenes judiciales, angustias ante un ejercicio de la justicia sometida o atada". Ídem, 15.

54. "La situación de injusticia que hemos descrito en la parte anterior nos hace reflexionar sobre el gran desafío que tiene nuestra pastoral para ayudar al hombre a pasar de situaciones menos humanas a más humanas. Las profundas diferencias sociales, la extrema pobreza y la violación de derechos humanos que se dan en muchas partes son retos a la evangelización. Nuestra misión de llevar a Dios a los hombres y los hombres a Dios implica también construir, entre ellos, una sociedad más fraterna". Ídem, 87.

55. Ídem, 13. 
la reticencia de 'un sector reaccionario de extrema derecha' que se beneficia de los privilegios de una 'estructura caduca'. Con todo, la carta hace mención a que este diálogo es posible por el trabajo de grupos comprometidos con los cambios estructurales. ${ }^{56}$

El presidente Carlos Humberto Romero, fuertemente presionado por Estados Unidos, que buscaba una salida a la crisis por medio de reformas que no cuestionasen seriamente el sistema, había intentado ir el encuentro de la crisis generalizada proponiendo una mesa de diálogo, el Foro Nacional, en mayo de 1979. Este Foro, al cual habían sido convocadas, junto a las fuerzas políticas pro gubernamentales, algunas de las fuerzas de la oposición, pronto se reveló incapaz de cumplir los objetivos ante la ausencia de las principales fuerzas de oposición, que argumentaban. Al mismo tiempo, se mantenía la vigencia de la Ley de Defensa y Garantía del Orden Público, una ley muy similar a un estado de sitio que justificaba la actuación de las fuerzas de represión.

La Carta comenta este llamado al diálogo de parte del gobierno haciéndose eco de algunos reclamos de las organizaciones populares: por un lado, ve la necesidad del diálogo como una salida posible a la crisis, pero lamenta que estén dadas las condiciones ${ }^{57}$ y la ausencia de una verdadera convocatoria a las fuerzas de la oposición. ${ }^{58}$

Romero plantea las condiciones para un diálogo que haga posible una salida a la crisis: la cesación de toda forma de violencia, ${ }^{59}$ la voluntad de propiciar cambios estructurales, ${ }^{60}$ el respeto a la libertad de organización popular ${ }^{61}$ y la

56. “...que es duro y conflictivo hablar de cambios de estructuras con quienes se están beneficiando de esas estructuras caducas. Pero, si es cierto que hay un sector reaccionario de extrema derecha, hay, por otra parte hombres sensibles al cambio y grupos empeñados activamente en trabajar por el cambio de las estructuras a fin de propiciar una situación favorable para todo el pueblo salvadoreño." Ídem, 59.

57. "El verdadero dialogo nacional es una necesidad del país como camino para salir de nuestra crisis; por eso, creo oportuno iluminar este tema, comenzando por lamentar que la convocatoria del gobierno a un diálogo nacional haya perdido una bella oportunidad por no haberlo dotado de sus debidas condiciones. Y así, desde el principio, aquel llamamiento tuvo una acogida pública muy fría que ya era una denuncia de la falta de confianza y libertad para expresar, en plan de igualdad, todas las inquietudes y voces vivas de la patria." Ídem, 82.

58. “...el diálogo nacional sería una burla si se redujera a un simple foro al que acudieran solamente los amigos del gobierno y aquellos que en el fondo no desean que se de un cambio profundo..." Ídem, 83.

59. "Otro elemento esencial de este diálogo es que cese toda forma de violencia, pues un diálogo busca la verdad y la justicia por la vía de la racionalidad y ésta necesita un ambiente de confianza y serenidad. Esto es particularmente válido respecto del gobierno. Mientras haya represión violenta y desproporcionada contra las protestas públicas, se dé el nivel actual de asesinatos por razones políticas, existan tantos presos políticos y desaparecidos y se mantengan fuera del país a líderes políticos, sociales y religiosos, no es posible hablar de diálogo. Sobre esto no hay que dialogar sino que es condición para un diálogo". Ídem, 83.

60. "No podemos creer en la efectividad del diálogo nacional si no se manifiesta la voluntad y la decisión de propiciar cambios que garanticen permanentemente mejor nivel de vida para todos los salvadoreños." Ídem.

61. "Otro tema importante del diálogo debe ser la libertad de organización. Nuestra inclinación 
comprensión por parte de los empresarios de la justicia de los reclamos 'para equilibrar el reparto de los producido por el trabajo y el capital' ${ }^{62}$

Este último concepto revela la comprensión profunda de parte de Romero de la situación del país, proponiendo un reparto equitativo de la riqueza producida, concepto que no se habían animado a proponer las organizaciones populares que habían optado por la vía armada. Éstas veían cómo el obispo se apropiaba de un argumento que quizá estaba en sus propuestas, pero que no había sido exteriorizado aún.

La última condición que Romero propone para un verdadero diálogo nacional está dirigida a las fuerzas de oposición: evitar los excesos en los reclamos y la manipulación por parte de elementos extraños. ${ }^{63}$

Las organizaciones populares respondieron a esta convocatoria con el llamado a un Foro Popular, a mediados de ese mismo año de $1979 .{ }^{64}$

\section{- Sobre la represión}

La represión por parte de las fuerzas armadas contra las organizaciones populares se había agudizado ya desde 1978, al amparo de la Ley de Defensa y Garantía del Orden Público. Esta Ley, creada en tiempos del propio presidente Romero en noviembre de $1977,{ }^{65}$ cuatro meses después del comienzo de su

y sentido cristiano nos lleva a preferir los métodos de reivindicación social basados en una organización de clases populares que se ajuste a los principios de la Constitución y que sean eminentemente pacíficos". Ídem

62. "Al intervenir en un diálogo nacional, los empresarios deben de comprender la lógica y la justicia del movimiento sindical, que no surgió para perjudicar a las empresas, de las que todos viven, sino para equilibrar el reparto de lo producido por el trabajo y el capital". Ídem

63. "Por otra parte, los sindicalistas y los obreros para ser dignos interlocutores de ese diálogo, conocedores de la eficacia de las fuerzas organizadas, no deben caer en el mismo pecado que critican, dejándose manipular por intereses ajenos al campo laboral o abusando del poder que da la solidaridad para hacer exigencias desproporcionadas". Ídem

64. En septiembre de 1979 quedó conformado el Foro Popular, ante la iniciativa de varias organizaciones populares: la influyente Federación Nacional de Trabajadores Salvadoreños (FENASTRAS), el Frente de Acción Popular Unificada (FAPU), las Ligas Populares 28 de Febrero (LP-28), La Unión Democrática Nacionalista (UDN), ligada al Partido Comunista Salvadoreño, el Partido Demócrata Cristiano (PDC), el Movimiento Nacional Revolucionario (MNR), de orientación socialdemócrata y el partido Unionista Centroamericano (PUCA).

65. “I. Que es deber fundamental del Estado dictar las disposiciones que sean necesarias para garantizar el mantenimiento del sistema republicano, democrático y representativo del Gobierno; II. Que el Artículo 158, inciso segundo de la misma Constitución prohíbe la propaganda de doctrinas anárquicas o contrarias a la democracia, y ante la gravedad de los acontecimientos terroristas y los provocados por la subversión internacional, el Gobierno de la República debe contar con instrumentos legales que aseguren el ejercicio de los derechos individuales y la libertad de los miembros de la comunidad, satisfaciendo así las justas exigencias de la moral, el orden público y el bienestar general de la sociedad, dando plena vigencia a la Declaración Universal de los Derechos Humanos, aprobada y proclamada por la Asamblea General de las Naciones Unidas el 10 de diciembre de 1948”. Decreto de creación de la Ley de Defensa y Garantía de Orden Público. La Comisión Interamericana de Derechos Humanos, de la Organización de los Estados Americanos, recomendaba en 1978. "Eliminar las disposiciones que dan lugar a una interpretación demasiado amplia de sus actuales normas y a una aplicación indiscriminada de ellas, porque han dado lugar a importantes 
mandato, se constituyó en el instrumento legal que amparaba la represión.

La Ley había sido seriamente cuestionada por diversos sectores populares y políticos: el cuestionamiento partió de las organizaciones populares urbanas, como FAPU, BPR y LP-28, y de los partidos políticos como el Partido Demócrata Cristiano, el Movimiento Nacional Revolucionario y la Unión Democrática Nacionalista. Éstos últimos consideraban la Ley como el resultado de presiones de minorías privilegiadas que buscaban asegurar la tranquilidad de sus privilegios 'a costa de los legítimos intereses y necesidades de la gran mayoría de los salvadoreños'; denunciaban que la Ley como un instrumento arbitrario que llevaba a un estado totalitario, y que, invocando la protección de los derechos humanos, los viola constantemente. ${ }^{66}$

Romero, cercano a los sectores marginados y a los que más sufrían la represión, pinta en su Carta un panorama lúcido de la represión. La agudización de la violencia represiva por parte del estado, ya denunciada en su Tercera Carta Pastoral, llevó a Romero a plantear la exigencia del cese de la represión, en lo que insistirá frecuentemente hasta la homilía del 23 de marzo de 1980, y que probablemente lo llevó a la muerte. La represión, que adquiría una forma cada vez más 'violenta, alevosa e injusta', sufrida por campesinos, obreros y pobladores de tugurios organizados, podía encontrar en esta Ley su sustento jurídico.

La Carta denuncia además el sustento ideológico de la represión, partiendo de juicios tomados del documento de Puebla: la represión en El Salvador en esos años está sustentada por la Doctrina de la Seguridad Nacional, que lleva a estados totalitarios, a la violación de los derechos humanos, al uso abusivo e injustificado de la fuerza y a una subjetiva confusión con el cristianismo. Esta doctrina justificaba la actuación de los regímenes dictatoriales latinoamericanos entre los años 1970 y 1990. También aquí hace alusión al documento de Puebla. ${ }^{67}$ La Carta detalla algunas manifestaciones de la represión: violencia sistemática, selectiva y desproporcionada, delaciones, torturas, desapariciones, inseguridad jurídica...68. La Oficina de Socorro Jurídico del arzobispado de San salvador,

actos de abuso de poder, en perjuicio del libre y normal desenvolvimiento de los opositores al gobierno", en http://www.cidh.org/countryrep/ElSalvador78sp/conclusiones.htm

66. “...un instrumento legal típicamente totalitario porque reúne los siguientes requisitos: gran amplitud delictiva y severidad penal; total ambigüedad en la tipificación, a fin de poderla aplicar a su gusto y arbitrio; y plena subjetividad en lo que se considera subversivo, anti-democrático, contrario al gobierno, a la seguridad nacional, a las instituciones estatales...”. Anónimo, El Salvador: La "Ley de defensa y garantía del orden público": Una amenaza a los derechos humanos, en revista NUEVA SOCIEDAD NRO.34, ENERO-FEBRERO 1978, PP. 151-153, San Salvador, 3 de enero de 1978, en enhttp://www.nuso.org/upload/articulos/402_1.pdf, consultado el 22.09.14

67. "Sería conveniente indicar aquí, también el fundamento ideológico de esta represión injusta. Se trata de la ideología de la seguridad nacional que el documento de Puebla denuncia con dureza en repetidas ocasiones". Ídem, 17 y 46

68. “...angustias de esta represión sistemática o selectiva acompañada de delación, violación de privacidad, apremios desproporcionados, torturas, exilios. Angustias en tantas familias por desaparición de sus seres queridos de quienes no pueden tener noticia alguna. Inseguridad total 
creada por el predecesor de Monseñor Romero, Luis Chávez y González, recibía denuncias de asesinatos, desapariciones y amenazas a quienes formaban parte de alguna organización popular, ${ }^{69}$ que después Romero citaba en sus homilías de los domingos, y que en esta Carta menciona para describir el ambiente de inseguridad.

\section{- Sobre la organización popular}

La organización popular, especialmente en los sectores rurales, sufrió una creciente represión y una constante vigilancia a partir de fines de la década de los años 70. Por el contrario, las organizaciones de patrones y hacendados eran permitidas y alentadas. ${ }^{70}$ En ambos casos, la Organización para gubernamental Organización Democrática Nacionalista (ORDEN) llevó a cabo un trabajo intenso, de vigilancia, represión, y reclutamiento.

La Carta menciona los obstáculos que encuentran las iniciativas gubernamentales para llevar a cabo reformas que conduzcan a un mejoramiento en las condiciones de vida de las personas que viven el los sectores rurales. Estos intentos se acentuarán cuando la Junta de Revolucionaria Gobierno surgida del golpe de estado de octubre de 1979 proponga la reforma agraria. La oligarquía terrateniente se opuso tenazmente a toda reforma que implicase una disminución de los privilegios: su miopía le impidió percatarse que ello podría significar la reducción de las tensiones sociales. ${ }^{71}$

En esta Cuarta Carta, de 1979, Romero insiste en lo que proponía en la Tercera, de 1978, referido al derecho de organización, especialmente en los sectores rurales y en las organizaciones populares en general. Esta insistencia de Romero en un documento formal revela una decidida opción por el derecho de organización, el apoyo a las reivindicaciones populares. ${ }^{72}$

Romero advierte, además, a las organizaciones populares, especialmente a las que eligieron la vía armada como camino hacia una sociedad sin injusticias, el peligro

por detenciones sin órdenes judiciales, angustias ante un ejercicio de la justicia sometida o atada..." Ídem, 15.

69. "Los datos sobre muertos y desaparecidos denuncian un ambiente de impunidad propicio para la proliferación y actividad de organizaciones asesinas de ultra derecha que han agravado el panorama de la violencia en el país... Ídem, 15.

70. "Se ve con malos ojos la organización de obreros campesinos y sectores populares y se adoptan medidas represivas para impedirla. Este tipo de control y de limitación de la acción no acontece con las agrupaciones patronales que pueden ejercer todo su poder para asegurar sus intereses...". 14, citando a Puebla”. Ídem, 14, citando al documento de Puebla.

71. “...la oposición cerrada de importantes sectores del capital a todas aquellas iniciativas populares o del gobierno que, a través de la organización gremial, buscan mejorar las condiciones de vida y elevar los niveles de salarios de las clases populares. Estos sectores dominantes sobre todo el agropecuario, no pueden admitir la sindicalización campesina ni obrera, mientras, con mentalidad capitalista, la consideren peligro de sus intereses económicos. La represión contra las organizaciones populares se convierte, para esa mentalidad, en una especie de necesidad para mantener y aumentar los niveles de ganancia, aunque sea a costa de la pobreza creciente de las clases trabajadoras." Ídem, 16.

72. Ídem, 29 y 50. 
de la absolutización de la organización: con frecuencia se ha llegado a considerar la organización como un valor superior a la persona humana y que con en algunas ocasiones se pone por encima de la libertad y de los derechos de los militantes, y donde los intereses de la organización van a tomar el lugar de las personas. ${ }^{73}$ Se crean así espacios sociales ficticios, inexistentes, donde las necesidades de las personas se ven suplantadas por necesidades de la organización.

Esta absolutización puede derivar en el desinterés por los problemas reales, la prescindencia de las creencias cristianas de muchos de sus integrantes, y transformar una verdadera fuerza social en un obstáculo para los intereses del propio pueblo. ${ }^{74}$

\section{- Sobre la violencia}

La radicalización de las opciones de Romero se manifiesta desde mediados de 1978. Su tercera Carta Pastoral marca un giro en la exteriorización formal de estas opciones. Su Cuarta carta Pastoral es una reafirmación de lo presentado en la anterior. Cuestiones como las organizaciones populares, la crisis del país y la violencia son tratadas con insistencia. En la cuestión de la violencia, precisamente, insiste en el año 1978 lo presentado un año antes.

En agosto de 1979 Romero había recibido la noticia del asesinato de tres sacerdotes de su diócesis, y de cientos de campesinos y militantes de las organizaciones populares; a algunos de ellos, los conocía personalmente, como a Apolinario Serrano, 'Polín', asesinado el 29 de setiembre de 1979, pocos días después de esta Cuarta Carta Pastoral, junto a Félix García Grande, su esposa Patricia Puertas y José López, los cuatro miembros de la Federación Cristiana de Campesinos Salvadoreños (FECCAS).

En 1979 Romero hace pública una sospecha que para muchos militantes de las organizaciones populares era una certeza: la permisividad del gobierno para con los actores de la violencia de derecha, permisividad que para muchos era complicidad y para otros impotencia. ${ }^{75}$

73. “...absolutización de la organización en la que caen muchos miembros de ciertas organizaciones populares que consideran como valor supremo su propia organización y a ella subordinan todo lo demás... la absolutización de la organización parte de algo fundamentalmente bueno porque surge del pueblo, en uso del derecho de organización para procurar, teóricamente el bien del mismo pueblo. Pero luego, en la práctica, se fanatiza de modo que ya no son los interese populares los que más interesan sino los del grupo u organización.” Ídem, 49.

74. "La dirigencia de una organización, absolutizada por el problema político de la toma de poder, puede desinteresarse prácticamente de otros problemas reales o desentender los criterios ideológicos de la base, que son los mismos problemas y criterios que interesan a la mayoría del pueblo, por ejemplo algunas necesidades socio-económicas más inmediatas, o los principios cristianos de sus organizados; tal puede ser la opción de alguna estrategia que puede ofender, sin necesidad, los sentimientos de religiosidad del pueblo, por ejemplo la toma de templos... Lo más grave de este fanatismo de la organización es que convierte una posible fuerza del pueblo en un obstáculo para los mismos intereses del pueblo y para un cambio social profundo." ídem, 49. 75. "El gobierno se muestra impotente para detener la escalada de la violencia en el país. Más aún, una sospechosa tolerancia de bandas armadas que, por su persecución implacable a los oponentes del gobierno, podrían considerarse como servidoras suyas, contradicen, en la práctica, 
Al mismo tiempo, reitera la condena explícita en la Tercera Carta a ciertas formas de violencia para las cuales no encuentra justificación: la violencia estructural, ${ }^{76}$ la violencia de grupos armados de derecha ${ }^{77}$ cuya libertad de acción hace sospechar de la complicidad de las fuerzas $\operatorname{armadas}^{78}$ y la violencia de grupos.

Y, al igual que en el año anterior, Romero mantiene la postura tradicional de la Iglesia acerca del 'derecho de insurrección', explícito ya desde 1967 en la encíclica Populorum Progressio, del papa Pablo VI, justificándolo sólo en casos de 'tiranía evidente y prolongada'. La encíclica hace alusión a situaciones cuya injusticia clama al cielo', para justificar una revuelta revolucionaria. ${ }^{79}$ Romero se apoya en ello en esta Carta. ${ }^{80}$

\section{- Sobre la división en la Iglesia católica}

La Iglesia católica ha sido tradicionalmente, jerárquica y monolítica. Así se manifestó a lo largo de su historia en El Salvador, con algunas escasas excepciones. Sin embargo, y especialmente después del 1968 y del documento de Medellín, cuando muchos sacerdotes quisieron poner en práctica las recomendaciones de este documento, y especialmente cuando las comunidades eclesiales de base en el país comenzaron a criticar la distribución desigual de la riqueza en el país, cuestionando así un orden social del cual al jerarquía de la Iglesia había sido celosa garante, surgieron fuertes y numerosas diferencias, que llegó hasta la jerarquía. Las divisiones en el seno de la pequeña Conferencia Episcopal de El Salvador en tiempos de Romero fueron evidentes y, para algunos, escandalosas.

Probablemente la manifestación más notoria fue la publicación de la carta Declaración del Episcopado de El Salvador sobre algunas Organizaciones

las enfáticas declaraciones del gobierno contra toda clase de violencia...”. Ídem, 15.

76. "La Iglesia condena 'la violencia estructural' o 'institucionalizada', 'producto de una situación de injusticia en la que mayoría de los hombres, mujeres y, sobre todo, niños, en nuestro país, se ven privados de lo necesario para vivir' ( $3^{a}$ Carta Pastoral). La Iglesia condena esta violencia, no sólo porque es injusta en sí misma y es objetivación de pecados personales y colectivos sino también porque es causante de otros sin número de crueles y más visibles violencias" ídem, 70.

77. El Informe de la comisión de las Naciones Unidas, la Comisión de la Verdad, surgida de los Acuerdos de Paz de 1992, De la locura a la esperanza, señala la práctica de la violencia por parte de grupos de derecha que actuaban bajo la tipología de 'escuadrones de la muerte'. Entre los años 1978 y 1980 actuaban en el país diversos grupos violentos de derecha. Algunos de ellos eran: la Brigada AntiComunista Maximiliano Hernández Martínez, las Brigadas Proletarias Salvadoreñas, la Unión Guerrera Blanca (Mano Blanca) (UDB) y la Organización para la Liberación del Comunismo (OLC).

78. “...la Iglesia condena la violencia por bandas terroristas de derecha que, por su absoluta impunidad se hacen sospechosas de connivencia oficial y han enlutado el magisterio nacional, las organizaciones populares, los políticos y la misma Iglesia. Su intención, insostenible evidentemente, es tratar de mantener el orden social injusto a que me he referido arriba y, por eso principalmente, participan de la injusticia del sistema". Ídem, 72

79. Pablo VI, Populorum Progressio, 30-31, 1967.

80. “...es legítima una insurrección en el caso muy excepcional de tiranía evidente y prolongada que atenta gravemente contra los derechos de la persona y damnificara peligrosamente el bien común del país ya provenga de una persona, ya de estructuras evidentemente injustas" (Cfr. $3^{a}$ Carta Pastoral)". Ídem, 74. 
políticas populares, donde se presentaba una visión distinta de la Tercera Carta Pastoral de Romero, escrita junto a Monseñor Rivera Damas. Esta declaración presentaba una aparente unidad del episcopado al presentarse como una declaración 'del Episcopado’.

Romero comentará sobre esta división con frecuencia en su Diario. En esta carta, presenta esta división como un reflejo de la división que existe en la misma sociedad salvadoreña. ${ }^{81}$

- Sobre la riqueza, la propiedad privada y las minorías privilegiadas Ya desde su Tercera Carta Pastoral, en agosto de 1978, Romero había comenzado a llamar la atención de la oligarquía, con una cierta frecuencia. Esos llamados estaban dirigidos a compartir la riqueza. En una homilía de febrero de 1979 había llamado a la oligarquía a participar en la solución de la crisis social otorgándole al capital un sentido social. Aludiendo a la idea de la opción preferencial por los pobres, surgida en la Conferencia de Puebla, Romero dice que esta idea no quiere excluir a quienes tienen riquezas, sino más bien, abrir los espacios para su participación en la solución de los problemas. ${ }^{82}$

En su Cuarta Carta Pastoral Romero introduce por primera vez en una carta pastoral la cuestión de la riqueza. Ya había hablado sobre la absolutización de la riqueza y de la propiedad privada en sus homilías, pero nunca lo había hecho en una Carta Pastoral. Se apoya, en esto, en los documentos del CELAM, y especialmente en el de Puebla, al tratar sobre la propiedad privada.

Al denunciar la absolutización de la riqueza Romero alude directamente a las clases privilegiadas, a las cuales ya había hecho mención en esta misma Carta al hablar de la 'violencia estructural', producto de las injusticias del sistema, como 'causante de otros sin número de crueles y más visibles violencias', como se citaba arriba. Ahora Romero encara la cuestión que califica como 'idolatría de la riqueza' ${ }^{83}$

La influencia del documento de Puebla se deja ver al momento de tratar la cuestión de la propiedad privada, un tema álgido para los sectores ligados a

81. “... el pecado más visible que la encuesta señala es la desunión de una Iglesia que debe tener la unidad como nota de su autenticidad. Nuestras comunidades señalan que cuando esta división afecta a la misma jerarquía y a los sacerdotes se origina más confusión en el Pueblo de Dios... esta desunión al interno de la Iglesia no es más que un eco de la división que existe a su alrededor, en la sociedad en que vive y trabaja." Ídem, 23.

82. "...que esto no quiere decir exclusión de los ricos, sino que quiere decir: llamamiento también a los ricos para sentir como suyos el problema de los pobres, y para estudiar, junto con el Gobierno en un diálogo, con los técnicos, con los que pueden resolver este callejón sin salida de El Salvador. Tienen obligación de estudiar y poner todos los medios a su alcance como si se tratara de resolver su propio problema. No se resuelve el problema con mandar los capitales al extranjero; es necesario ponerlos a funcionar en un verdadero sentido social...". Homilía en la misa del 18.02.1979, en http://servicioskoinonia.org/romero/homilias/B/790218.htm, recuperado el 30.09.2014.

83. “...esta idolatría de la riqueza impide a la mayoría disfrutar de los bienes que el Creador hizo para todos y lleva a la minoría que lo posee todo a un gozo exagerado de esos bienes". Ídem, 43. 
los privilegios. El concepto de 'hipoteca social' relativo a la propiedad privada, acuñado por el documento de Puebla ${ }^{84}$ y citado por Romero, sin duda no fue bien recibido por sectores de la oligarquía salvadoreña. Aquí Romero anima a estudiar los documentos del pensamiento social cristiano, de donde toma, precisamente, estos conceptos. ${ }^{85}$

La absolutización de la riqueza por parte de la oligarquía salvadoreña, que para Romero había sido la causa de la oposición a cualquier intento de reforma que intentase una distribución más justa de la riqueza, es presentada aquí como la causa de la violencia estructural que se mencionaba arriba. ${ }^{86}$

Romero dedica un apartado de su carta a dirigirse directamente a las minorías que ostentan el poder político o económico. Arriba les había recordado su responsabilidad en la generación de la violencia; ahora les recuerda su responsabilidad en la superación de la violencia y en el desarrollo del país. En una larga alusión a esta minoría, los anima a propiciar los cambios necesarios sin oponerse a ellos. Hace alusión aquí a la reforma agraria que había propuesto el presidente Molina, que tuvo que ser retirada de la agenda nacional por la oposición de los terratenientes. La participación equitativa de los recursos naturales redundará, en última instancia, en beneficio también de estas minorías. ${ }^{87}$

84. "492. Los bienes y riquezas del mundo, por su origen y naturaleza, según voluntad del Creador, son para servir efectivamente a la utilidad y provecho de todos y a cada uno delos hombres y los pueblos. De ahí que a todos y a cada uno les compete un derecho primario y fundamental, absolutamente inviolable, de usar solidariamente esos bienes, en la medida de lo necesario, para una realización digna de la persona humana. Todos los demás derechos, también el de propiedad y libre comercio, le están subordinados. Como nos enseña Juan Pablo II: «Sobre toda propiedad privada grava una hipoteca social»141. La propiedad compatible con aquel derecho primordial es más que nada un poder de gestión y administración, que si bien no excluye el dominio, no lo hace absoluto ni ilimitado. Debe ser fuente de libertad para todos, jamás de dominación ni privilegios. Es un deber grave y urgente hacerlo retornar a su finalidad primera 142". CELAM, Documento de Puebla, 492. Puede encontrarse en http://www.celam.org/doc_conferencias/ Documento_Conclusivo_Puebla.pdf. Los números 141 y 142 de esta cita refieren al Discurso inaugural del papa Pablo VI en la Conferencia de Puebla, y al numeral 28 de la encíclica Populorum Progressio.

85. "Es entonces cuando adquiere carácter urgente la enseñanza de la Iglesia según la cual sobre toda propiedad privada grava una hipoteca social. Este principio cristiano y evangélico terminará dando frutos de una distribución más justa y equitativa de los bienes...". Ídem, 44.

86. "La absolutización de la riqueza y de la propiedad lleva consigo la absolutización del poder político, social y económico, sin el cual no es posible mantener los privilegios aún a costa de la propia dignidad humana. En nuestro país, esta idolatría está en la raíz de violencia estructural y de la violencia represiva y es, en último término, la causante de gran parte de nuestro subdesarrollo económico social y político". Ídem, 45.

87. "En una sociedad como la nuestra, en la que la mayoría apenas tiene nada, esta minoría privilegiada, separada abismalmente de todos los demás, disfruta de niveles de vida semejantes a los que unos pocos disfrutan en los países más ricos. Tienen, además gran poder, precisamente por la estructura poco democrática de nuestra organización política. Ojalá por su propio interés y, todo, por dictado de la caridad, que consiste en dar a los demás lo propio y aún de sí mismo, propicien los cambios sociales en vez de frenarlos y de oponerse violentamente a ellos. Que juzguen, con honestidad, qué es lo más conveniente para todos y, a la larga, para sí mismos y para sus hijos, y recuerden la palabra de Jesús, que serán medidos, en esta vida y en la otra, con la misma medida con que ellos midan a los demás. Comprendemos que algunas acciones terroristas les mantengan en un estado de ánimo poco propicio a la serenidad y a la reflexión; pero deben superar esa preocupación 
Si bien en esos meses hubo intentos de acercamiento, probablemente sincero, de parte de la oligarquía a las necesidades del país, concretadas en visitas e Monseñor Romero, ${ }^{88}$ la oligarquía se opondrá tenazmente a los intentos de reforma de la Junta de Gobierno que surgirá del golpe de estado de octubre de $1 \mid 979$.

Este llamado a compartir los bienes, dirigido a la oligarquía salvadoreña, no estaba exento de riesgos: las reacciones de la poderosa oligarquía cuestionada no podían preverse. Romero iba aquí contra toda la tradición de la actuación de la Iglesia en la historia del país: no le faltaba coraje al obispo. Más aún, cuando situaba este llamado en el terreno de la justicia, fundamentándose en documentos que no podían ser sospechados de heterodoxia: citaba aquí el decreto Apostolicam Actuositatem (AA), del Concilio Vaticano II, de 1965. ${ }^{89}$

Pero la crítica a la oligarquía deriva aquí hacia la crítica al sistema: es la explotación de los trabajadores lo que hace posible el mantenimiento del sistema y de sus privilegiados. ${ }^{90}$

\section{- Sobre las fuerzas armadas}

Merece especial atención la alusión a las fuerzas armadas en esta Carta. A mediados de 1979, la represión comenzaba su período más violento. Las diversas fuerzas armadas: el ejército, la Policía Nacional la Policía de Hacienda y la Guardia Nacional ejercían una represión sobre las manifestaciones populares de oposición que el gobierno no controlaba. De hecho, la atención a esta cuestión será retomada por la proclama de las fuerzas armadas que tomarán el poder del golpe de estado de octubre de ese mismo año 1979; será retomada por el obispo

objetivas y plantear, generosamente las bases de una evolución democrática, donde la mayor parte de la población participe equitativamente de los recursos nacionales que son de todos. Así se arrancará la raíz principal de la violencia terrorista y de toda violencia injusta.” Ídem, 67.

88. "Lo más importante de esta mañana que fue muy ajetreada en el Arzobispado, fue la visita que luego fuimos a hacer a los señores Poma y De Sola. Dos dirigentes de la empresa privada que están muy preocupados por la situación del país y querían compartir conmigo la opinión sobre este asunto, ya que, según ellos, la Iglesia es la única que tiene una voz moral que puede conducir el país. Yo agradecí este aprecio, traté de escuchar sus opiniones y de dar con franqueza también la mía. Aunque no en todo estamos de acuerdo, creo que aceptan la dureza del Evangelio, de que sólo se puede hacer una verdadera paz si se hace una verdadera justicia. Y yo resalté mucho que era necesario el cambio de una estructura social, económica, política en el país. Por lo menos que el pueblo vea que se comienza con seriedad esta transformación, de lo contrario, no podemos detener esta ola de violencia." Monseñor Oscar Arnulfo Romero, Diario, edición a cargo del Arzobispado de San Salvador, San Salvador, pág. 270, nota del 28.08.1979. La reunión a que hace referencia esta nota en el Diario de Monseñor Romero fue tenida pocos días después de la publicación de la Cuarta carta Pastoral de Monseñor Romero.

89. “...cumplir antes que nada las exigencias de la justicia, para no dar como ayuda de caridad lo que ya se debe por razón de justicia; suprimir las causas, y no sólo los efectos de los males y organizar los auxilios de tal forma que quienes los reciben se vayan liberando progresivamente de la independencia externa y se vayan bastando por sí mismos" (A. A. 8)" (n. 1146).

90. "Analistas de nuestra economía señalan que al buen funcionamiento del sistema económico de El Salvador le conviene disponer de mano de obra abundante y barata. Cafetaleros, cañeros, algodoneros y demás elementos del sector agro-exportador, necesitan que el campesino no tenga trabajo ni esté organizado, a fin de poder contar con esa mano de obra abundante y barata para levantar y exporta sus cosechas." Ídem, 16. 
Romero en su advertencia a la Democracia Cristina a principios de 1980, cuando ésta integre la Junta de Gobierno surgida del golpe de estado; y será motivo de preocupación constante de parte del obispo, que lo llevará a pedir el cese de la represión en su homilía del 23 de marzo de 1980, un día antes de su asesinato. Romero recibía con frecuencia la visita de militares, especialmente después del golpe de octubre de 1979. Sin embargo, ya desde antes las visitas al arzobispo de partt6e de los militares del gobierno que presidía el coronel Calos Humberto Romero tenían alguna frecuencia. La violencia creciente y la crisis de la que todos hablaban ya estaba siempre entre las conversaciones y las consultas. ${ }^{91}$

La Carta alude a la independencia con que actúan las fuerzas armadas, que 'oprimen y reprimen' toda manifestación que cuestione el sistema. Conceptos como el de 'el pueblo sometido a la tutela de los militares', ${ }^{92} \mathrm{O}$ 'la fuerza armada convertida en guardia de los intereses de la oligarquía', ${ }^{93}$ no podían dejar de causar malestar entre las misma fuerzas armadas y entre la oligarquía local.

\section{- Misión de la Iglesia}

La idea central de la Carta es clarificar 'la misión de la Iglesia en medio a la crisis que vive el país', como lo dice su título. En esta clarificación Romero va desarrollando los dos conceptos principales de su Carta: la justicia de la organización popular y la idea de una sociedad 'más fraterna'.

La primera idea tiene que ver con la utopía que con frecuencia se presenta en algunos sectores eclesiales cercanos a la teología de la liberación, cercanos al

91. "Fue un día trágico. Amaneció la noticia del asesinato del hermano del Presidente de la República, un profesor retirado que vivía en Apopa. Vino a visitarme el secretario, el subsecretario del ministerio de defensa, coronel Iraheta, quien me dijo que el Presidente y el Ministro de defensa y otros hombres de gobierno habían conversado, en la velación del difunto, acerca del peligro que yo corría, y que me ofrecían la seguridad que yo quisiera, incluso un carro blindado. ... diciéndole respetuosamente que no aceptaba esa protección ya que yo quería correr los mismos riesgos que está corriendo el pueblo... Aproveché para pedirles, más bien protección para para el pueblo en ciertas zonas donde los retenes, los operativos militares hacen tantos estragos, o por lo menos, siembran tanto terror. Le manifesté que yo mismo había sido objeto de vejaciones cuando al entrar a Arcatao me pusieron con las manos arriba y me registraron...". Monseñor Oscar Arnulfo Romero, Diario, edición a cargo del Arzobispado de San Salvador, San Salvador, pág. 276, nota del 07.09.1979. Esta entrevista de Romero con el Sub secretario de Defensa tuvo lugar un mes antes del golpe de estado de octubre de 1979.

92. "El pueblo es sometido a la tutela de elites militares y políticas que oprimen y reprimen a todos los que se opongan a sus determinaciones, en nombre de una supuesta guerra total. La fuerza armada es la encargada de cuidar la estructura económica y política con el pretexto de que ese es el interés y seguridad nacional. Todo el que no esté de acuerdo con el Estado es declarado como enemigo de la nación y como exigencias de esa seguridad nacional se justifican muchos "asesinatos, desapariciones, prisiones arbitrarias, actos de terrorismo, secuestros, torturas... demuestran un total irrespeto a la dignidad de la persona humana". Ídem, 46. Nuevamente hace referencia al documento de Puebla, ahora en el numeral 1262.

93. "Se desorienta la noble función de la fuerza armada que, en vez de servir a los verdaderos intereses nacionales, se convierte en guardia de los intereses de la oligarquía, fomentando así su propia corrupción ideológica y económica. Algo parecido ocurre con los cuerpos de seguridad que, en vez de cuidar el orden cívico, se hacen fundamentalmente organismos represores de los disidentes políticos, y finalmente, el estado mayor sustituye inconstitucionalmente las instancias políticas que deberían decidir democráticamente el curso político del país." Ídem, 47 
concepto de 'reino de Dios', ${ }^{94}$ tomado del documento de Medellín, presentado como una sociedad sin desigualdades y donde la fraternidad actúa como norma ética común. ${ }^{95}$

Este concepto de una sociedad que se acerque a la justicia y donde no existen las desigualdades era una idea común entre los debates de las izquierdas, especialmente entre aquellos movimientos populares que habían optado por la violencia y la vía armada como camino hacia la toma del poder político, desde el cual debía construirse la utopía. La propuesta de Romero de una 'sociedad más fraterna'96 quitaba argumentos a los sectores de la oposición: la propuesta que las fuerzas populares armadas hacían desde la clandestinidad, y que justificaba la acción armada, se hacía ahora desde la más alta autoridad de la Iglesia católica, en un documento oficial y publicada en todo el país.

La segunda idea ya estaba planteada en la Tercera Carta Pastoral, de agosto de 1978, y le había ganado fuertes críticas de parte de los sectores cuyos privilegios eran cuestionados por estas organizaciones populares. En esta Cuarta Carta, Romero da un paso más en la radicalización de sus opciones en este sentido, al plantear la defensa de la organización popular como una acción a llevar a cabo por la evangelización. De hecho, el concepto 'alentar la organización' es un subtítulo en esta Carta. ${ }^{97}$ El empleo del concepto 'evangelización', 98 que tiene que ver con la esencia misma de la misión de la Iglesia, pone la cuestión de la organización popular en el plano de la misión de la Iglesia: la organización popular es una tarea esencial en la evangelización. ${ }^{99}$ Tampoco podía pasar desapercibido este concepto para las clases privilegiadas, especialmente para

94. Cfr., Víctor Manuel Guerra Reyes, La concepción del Reino de Dios de Monseñor Romero, tesis para la Maestría en Teología por la Universidad Centroamericana José Simeón Cañas (UCA), San Salvador, 1999, dirigida por Dr. Rafael De Sivatte.

95. "...voz de los que no tienen voz, defensora de los derechos de los pobres, animadora de todo anhelo justo de liberación, orientadora, potenciadora y humanizadora de toda lucha legítima por conseguir una sociedad más justa que prepare el camino al verdadero Reino de Dios en la historia. Esto exige a la Iglesia una mayor inserción entre los pobres, con quienes debe solidarizarse hasta en sus riesgos y en su destino de persecución, dispuesta a dar el máximo testimonio de amor por defender y promover a quienes Jesús amó con preferencia." Ídem, 56.

96. "La situación de injusticia que hemos descrito en la parte anterior nos hace reflexionar sobre el gran desafío que tiene nuestra pastoral para ayudar al hombre a pasar de situaciones menos humanas a más humanas. Las profundas diferencias sociales, la extrema pobreza y la violación de derechos humanos que se dan en muchas partes son retos a la evangelización. Nuestra misión de llevar a Dios a los hombres y los hombres a Dios implica también construir, entre ellos, una sociedad más fraterna". Ídem, 87.

97. Ídem, 65.

98. "La evangelización, aquí y ahora, tiene que defender y alentar la organización social y política de las masas campesinas, obreras, etc. Gracias a Dios, esta tarea ya cuenta con laicos cristianos muy capacitados a quienes la Iglesia ofrece, como dijo el Papa Pablo VI, "una inspiración de fe, una motivación de amor fraterno, una doctrina social como base de su prudencia y de su experiencia". Ídem, 65. Nuevamente, Romero se apoya en un documento de la Iglesia, esta vez en un documento del Concilio Vaticano II, Evangelii Nuntiandi, numeral 38.

99. "En mi Tercera Carta Pastoral, defendí, con la doctrina de la Iglesia el derecho de organización que también la constitución del país consagra para los salvadoreños. No se trata solamente de un derecho, sino de una necesidad y obligación para promover un orden más justo que realmente tenga en cuenta a las mayorías del país". Ídem, 65. 
aquellos sectores ligados a la Iglesia católica desde mucho tiempo atrás, y que habían creído con sinceridad es un orden donde la Iglesia apoyaba sus privilegios. Este concepto cambiaba el cristianismo en el que la oligarquía había creído desde hacía siglos.

\section{Monseñor Romero y los medios de comunicación}

Los medios de comunicación masiva en El Salvador han estado al servicio del sistema, especialmente la prensa escrita. Los dos diarios de mayor difusión en el país son La Prensa Gráfica y El Diario de Hoy, ambos de una marcada tendencia conservadora; a ellos hay que sumarle el Diario latino, que en los años de Romero en San Salvador se empeñó en una campaña de difamación.

La relación de Monseñor Romero con estos medios de comunicación no fue conflictiva en los años anteriores a su llegada a San Salvador, salvo algún desencuentro sin demasiada trascendencia. Sin embargo, ya desde los primeros pasos de Monseñor Romero como arzobispo de San Salvador, desde marzo de 1977, la relación fue haciéndose cada vez más tirante. Esto reflejado en las publicaciones de los medios de comunicación y en los comentarios de Monseñor Romero en sus homilías y en los programas semi oficiales de la radio del arzobispado.

Romero fue un gran comunicador. Él mismo dirigió personalmente los periódicos Chaparrastique en San Miguel, y Orientación en San Salvador. Hizo uso de los medios de comunicación masiva a pesar de los obstáculos que los mismos medios le ponían. Aún considerando el insustituible trabajo que realizaban, el llamado a los medios a no dejarse manipular por los intereses materialistas fue constante. Este llamado incluía el pedido de dejar de lado posturas cómodas que sólo contribuían a mantener el sistema sin mayores cambios, manteniendo los mismos intereses y privilegios.

Y con frecuencia acusó a los medios de comunicación de estar al servicio de quienes tenían el poder económico: palabras como 'plumas vendidas', y 'lenguas que se alimentan de la mentira', constituyeron algunos de los términos con los que el arzobispo cuestionaba la actuación de los medios de comunicación. ${ }^{100}$

100. “...Quiero decir que estos medios maravillosos como son el periódico, la radio, la televisión, el cine, donde grandes masas humanas están comunicando un pensamiento, muchas veces son instrumentos de confusión. Estos instrumentos artífices de la opinión común, muchas veces se utilizan manipulados por intereses materialistas, y así se convierten en mantenedores de un status injusto, de la mentira, de la confusión; se irrespeta uno de los derechos más sagrados de la persona humana que es el derecho a estar informado, el derecho a la verdad. Ese derecho es el que cada uno tiene que defender por sí mismo haciéndose crítico al manejar los medios de comunicación social. No todo lo que está en el periódico, no todo lo que se ve en el cine, en la televisión, no todo lo que nos dice la radio es verdad. Muchas veces es, precisamente, lo contrario: la mentira... ¿Lástima tantas plumas vendidas, tantas lenguas que a través de la radio tienen que come $r$ y se alimentan de la calumnia porque es la que produce! La verdad muchas veces no produce dinero sino amarguras, pero vale más ser libre en la verdad que tener mucho dinero en la mentira!" Homilía en la misa del 07.05.1978, citado por Márquez Ochoa, Martirologio de Mons. Romero. Testimonio y catequesis de la Iglesia salvadoreña, Comunidades Eclesiales de 
El arzobispo criticó con frecuencia el sesgo de la información que los medios de información presentaban,acusándolos de manipulación, ${ }^{101}$ de montar campañas de difamación contra la Iglesia o contra él mismo, de fomentar una religión piadosa alejada de los problemas de las mayorías y de las injusticias, de interesarse más por el dinero y la mentira que por la transmisión de la verdad, ${ }^{102}$ de usar la defensa de la libertad de expresión en interés propio, ${ }^{103}$ de transformase en 'mercaderes de la información' ('mercaderes de informaciones deformes y silencios sospechosos'), ${ }^{104}$ de sembrar confusión y odio y de estar al

Base, San Salvador, sin fecha, pág. 135.

101. "En estos momentos en que la Iglesia se halla envueltas, muy a pesar suyo, por una marea de acusaciones y defensas, es necesariamente mostrar paladinamente cómo los medios de comunicación, y muy especialmente del país, manipulan la información que llega del Papa o de Puebla, con objeto de acumular munición para su incesante campaña contra Monseñor Romero y los ideales que él defiende". El Salvador entre el terror y la esperanza. Los sucesos de 1979 y su impacto en el drama salvadoreño de los años siguientes, Compilado por Rodolfo R. Campos, UCA Editores, San Salvador, 1982, pág. 53, programa del 29 de enero de 1979.

102. "Los hombre, y sobre todo, las mujeres piadosas debieran estar agradecidas a nuestros diarios. No solamente han dado una gran cobertura al viaje del papa sino que todos los días regalan a sus lectores con comentarios piadosos. No importa que quienes los escriben sean hombres sin piedad y también sin conocimiento teológico. Lo que importa es hacer una religión que deje de lado las obras cristianas de la fe".

En las páginas editoriales de El Diario de Hoy de esta fecha, se nos dice, por ejemplo, que la función de los sacerdotes es eminentemente espiritual, que en el mundo sobre el odio y hace falta el amor, que el Espíritu Santo vuelve a la Iglesia católica, que Puebla va a dar un adiós a la teología marxista dela liberación, que sacerdotes sí, líderes políticos no... Sólo quien esté interesado más por la mentira que por la verdad, más por el dinero que por el hombre, puede escribir así.". El Salvador entre el terror y la esperanza. Los sucesos de 1979 y su impacto en el drama salvadoreño de los años siguientes, Compilado por Rodolfo R. Campos, UCA Editores, San Salvador, 1982, pág. 57, programa del $1^{\circ}$. de febrero de 1979.

103. En abril de 1979, la radio del arzobispado sufrió repetidas interferencias en momentos en que transmitía mensajes del Monseñor Romero. El arzobispado criticó a los diarios porque no dieron a la noticia la trascendencia que tenía. "Hace ya tres semanas que los piratas del aire, a ciencia y conciencia del gobierno, se obstinan en interferir los programas de nuestra emisora, especialmente cuando habla Monseñor Romero y cuando s emite nuestro programa de noticias y comentarios. Ni los piratas han dejado de piratear como si lo que aquí rigiera fuera la ley de la selva. Ni el gobierno ha intervenido eficazmente detectando quiénes son los violentos secuestradores de la voz del Arzobispo y los violadores de un derecho fundamental de los que queremos escuchar la voz de Monseñor Romero. Ni nuestros medios de comunicación se han preocupado de que se esté negando en el país, de modo tan brutal, el derecho de libre expresión del pensamiento y la legalidad vigente en el uso de las frecuencias radiales." El Salvador entre el terror y la esperanza. Los sucesos de 1979 y su impacto en el drama salvadoreño de los años siguientes, Compilado por Rodolfo R. Campos, UCA Editores, San Salvador, 1982, pág. 205, programa del 16 de abril de 1979.

104. En alusión a los editorialistas de un matutino, que mencionaba los mercaderes de la Venecia del siglo XV, la radio del arzobispado comentaba: "Lástima porque venden algo podrido y sucio, como son las crónicas de crimen y sexo sin respeto alguno al público; lástima, porque para levantar sus grandes edificios tienen que recurrir a la mentira, a la calumnia, a la difamación; lástima porque han vendido su alma al mal poder y al mal dinero, a fin de silenciar las voces de los que protestan, de los que tienen algo que denunciar, y han dejado sin palabra al pueblo; y desprecio porque el mercader está en la calle vendiendo sus cosillas no merece que se le compare con los mercaderes que están en los diarios subidos precisamente en los editoriales diciéndonos las mentiras del día en las páginas de periódicos locales." El Salvador entre el terror y la esperanza. Los sucesos de 1979 y su impacto en el drama salvadoreño de los años siguientes, Compilado por Rodolfo R. Campos, UCA Editores, San Salvador, 1982, pág. 397, programa del 10 de agosto de 1979. 
servicio del capital. ${ }^{105}$

Efectivamente, con frecuencia los periódicos presentaban textos de documentos, como el de Medellín o Puebla ${ }^{106}$; o de discursos, como los del Papa o del mismo Monseñor Romero, parcialmente mutilados o incompletos, dando lugar a interpretaciones parciales.

Monseñor Romero 'tuvo mala prensa', expresaba Héctor dada Hirezi, refiriéndose a la prensa escrita de San Salvador. Los dos periódicos de mayor circulación, la Prensa Gráfica y El Diario de Hoy, ambos propiedad de la oligarquía, desataron su furia contra Romero a los pocos días de su llegada a San Salvador, cuando el arzobispo fue haciendo ver claramente que sus opciones no pasaban por sus intereses.

El Diario de Hoy comenzó una campaña 'criminal'107 contra Romero: 'haga patria, mete un cura', comenzó a leerse en muchos muros de la ciudad capital, y las fuerzas armadas acompañaron esta campaña. Los periódicos distorsionaban las noticias, publicándolas parcialmente o fuera de contexto, para perjudicar su imagen.

Con todo, Romero supo distinguir los dueños de los medios de comunicación de quienes escribían en esos medios. Si bien no aceptaba las tergiversaciones de la verdad de los medios de comunicación, y en ello se refirió a los periodistas de los medios de comunicación escrita y radial. ${ }^{108} \mathrm{El}$ 'diálogo' entre el arzobispo y los medios de comunicación fue intenso, constante y con posturas sumamente

105. "Nuestra prensa es sencillamente de pésima calidad intelectual y, a veces, de baja estofa moral. Su fuerte son los anuncios, sobre todo en los diarios matutinos, que más arecen catálogos comerciales que órganos de información y criterio. Su labor de información se reduce a un partidarismo descarado en favor del gran capital. Su primer mandamiento es la defensa del capitalismo, pero no de un capitalismo moderno y racional sino dl capitalismo criollo, del capitalismo tal como se da entre nosotros. Nunca dará una noticia y menso hará una campaña sin contar con los debidos permisos del capital y del gobierno." El Salvador entre el terror y la esperanza. Los sucesos de 1979 y su impacto en el drama salvadoreño de los años siguientes, Compilado por Rodolfo R. Campos, UCA Editores, San Salvador, 1982, pág. 66, programa del 8 de febrero de 1979.

106. El 26 de enero de 1979, el Diario Latino, en su página 4 reproducía un discurso del Papa en Santo Domingo, presentándolo como 'texto oficial'. Sin embargo, el texto estaba mutilado, faltando la frase 'que no haya trabajadores maltratados ni disminuidos en sus derechos'. El texto íntegro decía: '...que no haya campesinos sin tierra para vivir y desenvolverse dignamente, que no haya trabajadores maltratados ni disminuidos en sus derechos, que no haya sistemas que permiten la explotación del hombre por el hombre o por el estado.'

107. Concepto de Héctor Dada Hirezi, antiguo militante democristiano y ex integrante de la Junta Revolucionaria de Gobierno surgida después del golpe de estado de octubre de 1979, en entrevista del 05.11.2014.

108. "Si tú pagas por escribir o para hablar por radio ofensas contra tu hermano, aunque seas el Obispo, no eres cristiano. Tú, que te ganas a la vida, que por necesidad de tu estómago vendes tu pluma, tu lengua para hablar por radio, servir de intereses mezquinos, no eres cristiano; pero eres más comprensible, te comprendo, tienes hambre y tienes que vender aunque sea tu fama". Márquez Ochoa, Armando, Martirologio de Mons. Romero. Testimonio y catequesis martirial de la Iglesia salvadoreña, Comunidades eclesiales de base, San Salvador, sin fecha, pág. 150. 
firmes por parte de Romero, que se refirió al accionar de los medios con palabras durísimas. Con todo, Romero supo distinguir entre los dueños de los medios de comunicación, a quienes consideró siempre estar al servicio del sistema, y los profesionales de la información, empelados de esos mismos medios que criticaba. No se reservó palabras el arzobispo para referirse a los medios.

Con todo, nunca exigió Romero que haya un control de los medios de comunicación por parte de instancias del gobierno. La pasividad oficial frente a la actuación de los medios de comunicación resultaba sumamente llamativa en esos tiempos de radicalización. Ello permitió los programas de televisión de 1979 y 1980, donde Roberto D'Aubuisson podía amenazar públicamente a sus opositores sin reacciones de parte del gobierno. La empresa privada Telecorporación Salvadoreña abrió sus espacios a D'Aubuisson. Si bien Romero nunca se refirió a esto directamente, frecuentemente hizo alusión a las amenazas públicas impunes.

Sin embargo, la honestidad de Romero frente a los hechos le valió el reconocimiento de la prensa internacional, que los buscaba con frecuencia frente a los hechos más notorios de la vida nacional, especialmente en los años 1979 y 1980 . Y pronto se convirtió en el árbitro de la vida nacional, ${ }^{109}$ buscado por personas del gobierno, de las fuerzas armadas y de las organizaciones populares, para pedir apoyo o consejo frente a hechos decisivos. Romero 'decía siempre lo que él creía era la verdad, con suma honestidad', ${ }^{110} \mathrm{y}$, si bien no tenía una 'línea editorial', pero su constante e indudable honestidad frente a los hechos le otorgaba una credibilidad a la que todos, gobierno, fuerzas armadas, organizaciones populares urbanas y rurales, y hasta la guerrilla que había optado por la vía armada como solución a la crisis, terminaron por recurrir.

Pronto Romero fue solicitado continuamente, especialmente por medios de prensa extranjera, para conocer su opinión sobre los hechos de la semana, generalmente después de sus homilías de los domingos. ${ }^{111}$ Esto lo convirtió, ya desde el episodio de Aguilares en 1977, en una persona a tener en cuenta en todos los procesos políticos del país.

Al mismo tiempo, algunos grupos extremistas contrarios a cualquier cuestionamiento del sistema usaron la televisión para exteriorizar su radicalismo por medio de amenazas reiteradas en programas públicos contra los personajes de la oposición más conocidos. Con frecuencia, estas amenazas

109. Conceptos de José Jorge Simán Jacir, antiguo amigo personal de Monseñor Romero, ex integrante del gobierno de la Junta Revolucionaria de Gobierno surgida después del golpe de estado de octubre de 1979, en entrevista del 05.11.2014.

110. Conceptos de Héctor Dada Hirezi, antiguo militante democristiano y ex integrante de la Junta Revolucionaria de Gobierno surgida después del golpe de estado de octubre de 1979, en entrevista del 05.11.2014.

111. "Monseñor Romero se transformó así en una de las figuras predilectas de los representantes de los medios de comunicación, pero también en un actor político clave, aunque involuntario. A pesar de su casi obsesivo interés por resaltar en cada denuncia el aspecto pastoral y evangélico, otorgó a su iglesia un importante papel que continuaría a lo largo del conflicto." Cortina, María, El Salvador: Memoria Intacta, Editorial Geminis, sin otros datos editoriales, pág. 63. 
se transformaron en asesinatos bajo la modalidad de escuadrones de la muerte. Así, Marianela García Villas, fundadora y presidente de la no gubernamental Comisión de Derechos Humanos de El Salvador (CDHES), fue amenazada públicamente primero, por Roberto D’Aubuisson en su programa de televisión, y asesinada después, en 1983. ${ }^{112}$

En esos años, los periódicos extranjeros buscaron con frecuencia a Monseñor Romero para conocer sus comentarios con respecto a la realidad del país, comentarios que Romero no negaba. Generalmente, esos comentarios a la prensa extranjera habían sido ya presentados en sus homilías de los domingos, y que en general diferían de la realidad presentada por los periódicos nacionales. La prensa nacional criticó muchas veces a la prensa extranjera, acusándola de falsear la verdad, de intervenir en asuntos del país, de tramar conjuras internacionales para desacreditar el país y de desconocer la verdad. Raras veces la prensa extranjera contestaba estas críticas: el arzobispado, por su parte, mencionaba algunas veces estas diferencias. ${ }^{113}$

Ello originó constantes fricciones del gobierno con los medios de prensa extranjeros, a los dificultó su trabajo, acusándolos de emitir informaciones falsas y tendenciosas y de formar parte de planes comunistas para desestabilizar el gobierno. ${ }^{114}$

Precisamente, cuando el gobierno presidido por el general Romero proponía el diálogo nacional, y cuando la oposición dedicaba espacios informativos al diálogo alternativo propuesto por la oposición, los conflictos entre el gobierno y los medios de prensa extranjeros se agudizaron. ${ }^{115}$ Para ello, el gobierno utilizó los medios de prensa locales, que tildaban de mentirosos a los extranjeros. Un cartel en el único aeropuerto internacional del país decía 'Periodista, miente en tu país, no en el nuestro'.

112. http: / /www.contrapunto.com.sv/ddhh/marianella-victima-de-la-represion-y-la-impunidad 113. "En estos días hemos visto en algunos periódicos y en varias ediciones, cómo ciertos editorialistas locales se lamentan sobre las críticas que sobre nuestro país han publicado revistas y periódicos en el extranjero. Se ataca concretamente la desviación izquierdista de dos revistas y dos periódicos norteamericanos, trayendo a cuenta de una conjura internacional contra El Salvador." El Salvador entre el terror y la esperanza. Los sucesos de 1979 y su impacto en el drama salvadoreño de los años siguientes, Compilado por Rodolfo R. Campos, UCA Editores, San Salvador, 1982, pág. 189, programa del 4 de abril 1979.

114. "Ni uno solo de los gobiernos en turno ha dejado de calificarnos de desinformadores. Nos han acusado de ser parte de la estrategia comunista tendiente a desestabilizar el, sistema democrático". Cortina, María, El Salvador: Memoria Intacta, Geminis Editorial, sin otros datos editoriales, pág. 13.

115. "Fue en septiembre de 1979 cuando el gobierno del general Humberto Romero, lanzó sus primeras críticas públicas e implacables contra los periodistas extranjeros. Los editoriales de los diarios locales controlados por la extrema derecha, denunciaban la campaña de desprestigio lanzada por la prensa internacional contra El Salvador. Los empresarios montaron su primera ofensiva para 'corregir' la imagen difundida por los 'periódicos mentirosos', como les gritaban en plena calle a los colegas apenas los reconocían. Con ese fin, una delegación de hombres de empresa viajó a países de América y Europa. Años más tarde, sus hijos y en algunos casos sus nietos, conformarán la Asociación de Estudiantes Salvadoreños en el extranjero, un organismo de auténticos militantes extremistas, capaces de insultarnos y hasta golpearnos en lugares públicos". 
En ese contexto, los medios de prensa internacionales buscaban siempre a Monseñor Romero cuando querían conocer una opinión sobre algún acontecimiento. Y Romero siempre tuvo tiempo para los periodistas extranjeros; en su Diario narra numerosas reuniones que mantuvo con ellos, especialmente desde mediados de 1979 y durante los tres primeros meses de 1980.

Las actividades de Romero: sus misas, sus discursos y sus visitas a cantones y pueblos, y especialmente sus homilías, fueron seguidos con frecuencia por la prensa internacional: periódicos de México, Costa Rica, Estados Unidos, Francia, Suecia y de otros países de Europa transmitían muchas veces las misas del arzobispo, o buscaban entrevistarlo ante cualquier hecho de trascendencia en el país. ${ }^{116}$

Fue, probablemente, en los meses siguientes al golpe de estado de octubre de 1979 que los medios de comunicación nacionales pusieron en evidencia su papel de defensores de los intereses de la oligarquía. Ya desde los primeros anuncios de reformas por parte de la Junta Revolucionaria de Gobierno, los medios de comunicación escrita y radial adoptaron una postura francamente opositora, que no exteriorizaba un repudio al golpe de estado sino un rechazo de las reformas: el 7 de diciembre de 1979, un escrito formado por Dr. Hasbún en El Diario de Hoy pedía un golpe de estado contra la Junta de Gobierno para suplantar a sus miembros civiles por militares.

El arzobispado de San Salvador, que había abierto un compás de espera con respecto al golpe de estado, llamando a 'esperar a que las obras confirmen las palabras', llamando incluso a los movimientos populares que se habían opuesto al golpe a dejar de lado su oposición, por el momento, denunció abiertamente y con frecuencia la postura de los medios de comunicación, incluso después del golpe de octubre de 1979. ${ }^{117}$ De hecho, los periódicos continuaron con su

116. "Alegrarme también con ustedes, queridos hermanos que asisten a la catedral, porque nuestra misa ha sido objeto de crónicas de carácter internacional. Ustedes tal vez no se dieron cuenta. El 24 de Septiembre, día de la Virgen de las Mercedes, estuvo entre nosotros un periodista de la Prensa Asociada, que describió nuestra misa en un reportaje que se publicó en el extranjero y que aquí en el país no se publicó porque se refería a aquel ambiente tan triste frente a la catedral: un parque con gente armada.

También en la misa del domingo recién pasado tuvimos aquí el honor de que la televisión holandesa filmara nuestra misa -como lo hizo en la noche en El Calvario, en Santa Tecla-, llevándose una impresión muy grata de sentir, en la catedral, el palpitar de un pueblo que de veras asiste a misa no en una forma pasiva, sino que, en su silencio y en su oración, en su atención a la palabra de Dios, está siendo verdaderamente una participación viva". Monseñor Óscar A. Romero, Homilías, Tomo III, UCA Editores, San Salvador, 2006, pág. 328, misa del 30.10.1978.

117. "La Junta Revolucionaria de Gobierno tiene un serio problema con los medios de comunicación social. La casi casi totalidad de los medios de comunicación han tomado una clara posición contra el gobierno. Los medios no están por la revolución y no sólo no favorecen los cambios, no solamente no son imparciales o independientes, sino que están abiertamente contra ellos.... Los medios están en contra del gobierno por la razón básica de que o son propiedad de la oligarquía o son propiedad de personas fines a ella que tradicionalmente han servido y defendido." El Salvador entre el terror y la esperanza. Los sucesos de 1979 y su impacto en el drama salvadoreño de los años siguientes, Compilado por Rodolfo R. Campos, UCA Editores, San Salvador, 1982, pág. 735, programa del17 de diciembre de 1979. 
campaña contra la Iglesia católica, a la que se sumaría, en esos mismos meses, algunos programas de televisión.

Muchas personas fueron amenazados públicamente en los medios de comunicación, como le sucedió a Herbert Anaya, en 1987, ${ }^{118}$ Rubén Zamora, Mario Zamora y muchos otras personas, incluido Monseñor Romero. ${ }^{119}$ Muchas de estas personas salieron del país. ${ }^{120}$ Héctor Dada Hirezi, militante de la Democracia Cristiana y miembro de la Junta de Gobierno en los primeros meses de 1980, y que se fue del país el mismo día que renunció a la Junta, comentaba que 'yo soy el único que queda vivo de todos los que fueron amenazados' en esos tiempos. ${ }^{121}$

\section{Bibliografía}

López Vigil, María, ‘Monseñor Romero, piezas para un retrato', UCA Editores, San Salvador, $5^{\text {a }}$ ed. 2001.

Cortina, María, El Salvador: Memoria Intacta, Editorial Géminis, sin otros datos editoriales.

Chávez Orellana, Brenda Ivonne, Historiografía de la literatura testimonial y su apogeo en El Salvador en la década de los 80's. Aplicación de características a obras modélicas, Trabajo de grado para optar al grado de Licenciatura en Letras, San Salvador, El Salvador, Universidad de El Salvador.

Campos, Rodolfo R., El Salvador entre el terror y la esperanza. Los sucesos de 1979 y su impacto en el drama salvadoreño de los años siguientes, Compilado por, UCA Editores, San Salvador, 1982.

Márquez Ochoa, martirologio de Mons. Romero. Testimonio y catequesis martirial de la Iglesia salvadoreña, Comunidades Eclesiales de Base, San Salvador, sin fecha.

Monseñor Oscar Arnulfo Romero, Diario, edición a cargo del Arzobispado de San Salvador, San Salvador, 1989.

Gordon, Sara, Crisis política y guerra en El Salvador, Siglo XXI Editores, México, 1989.

118. La Comisión de la Verdad de las Naciones Unidas, surgida de los Acuerdos de Paz de 1992, en su Informe De la locura a la esperanza, presenta un informe sobre muchos casos de asesinatos, como los de Monseñor Romero, Herbert Anaya y otros.

119. “Monseñor Rivera y Damas pasó de ser uno de los críticos públicos del Romero-obispo al mejor amigo del arzobispo. Así lo reveló el propio Romero a un periodista mexicano en sus últimos días. Y como tal, Rivera presentía la muerte de Romero:

- La veía en varios sitios. Los grupos paramilitares le hacían acusaciones públicas. Se las hacía también el mayor Roberto D'Aubuisson en su programa de televisión. Y todos sabíamos lo que significaba ser señalado por esos personajes como enemigos de la patria. A mí no me habló nunca de su muerte. No había necesidad. Ambos sabíamos que podía estar en cualquier sitito, que le podía llegar a la vuelta de la esquina. Pero nada podíamos hacer para evitarla." Cortina, María, El Salvador: Memoria Intacta, Geminis Editorial, sin otros datos editoriales, pág. 65.

120. “La Comisión de Derechos Humanos perdió la cuenta de las amenazas que recibió Marianela. En aquel enero de 1980, la más reciente la había lanzado el mayor Roberto D'Aubuisson, la cabeza visible de la extrema derecha, a través de un programa de televisión. Monseñor Romero, Marianela, los hermanos Zamora, Mario y Rubén fueron señalados por el mayor como miembros de la guerrilla. De los cuatro, sólo Rubén logró evadir a la muerte con la que tantas veces lo cercaron." Cortina, María, El Salvador: Memoria Intacta, Geminis Editorial, sin otros datos editoriales, pág. 55-56.

121. Entrevista realizada por en San Salvador el 5 de noviembre de 2014. 
Baloyra, Enrique A., El Salvador en transición, UCA Ediciones, San Salvador, 1987.

Escobar Galindo, David; Horst, Enrique; Ter Nikken, Pedro; Mayorga, Román; Sánchez Cerén, Salvador; El Salvador, de la guerra civil a la paz negociada, Dirección de Cultura del Ministerio de Relaciones Exteriores, San Salvador, 2011.

Lino Rodríguez Arias, La democracia cristiana y América Latina. Testimonios de una posición revolucionaria, Editorial Universitaria, Lima, 1961.

Turcios, Roberto, Una vida por la democracia y la paz, en Escobar Galindo, D. et.al., El Salvador, de la guerra civil a la paz negociada, Dirección de Cultura del Ministerio de Relaciones Exteriores, San Salvador, 2011.

Castro Morán, Teniente Coronel Mariano, Función política del ejército salvadoreño en el presente siglo, Premio Nacional de Ensayo, UCA Editores, San Salvador, 1983.

La Prensa Gráfica, 16.08.1979, 17.08.1979.

Guerra y Guerra, R., Un golpe al amanecer. La verdadera historia de la proclama del 15 de octubre de 1979, Índole Editores, San Salvador, 2009.

Sobrino, Martín-Baró, Cardenal, La voz de los sin voz, UCA Editores, San Salvador, 2.000,

Luis Coto S. J., La Eclesiología en el pensamiento de Mons. Oscar A. Romero, ponencia en el II Simposio I Teológico sobre Monseñor Romero, Universidad Centroamericana José Simeón Cañas, UCA, 31.03.2005, en http://www.uca. edu.sv/cmr/semana_teologia.htm

Monseñor Romero, Cuarta Carta Pastoral, Misión de la Iglesia en medio de la crisis que vive el país, editada por el Arzobispado de San Salvador.

Anónimo, El Salvador: La "Ley de defensa y garantía del orden público": Una amenaza a los derechos humanos, en revista NUEVA SOCIEDAD NRO.34, ENERO-FEBRERO 1978, PP. 151-153, San Salvador, 3 de enero de 1978.

Pablo VI, Populorum Progressio, 30-31, 1967.

CELAM, Documento de Puebla.

Víctor Manuel Guerra Reyes, La concepción del Reino de Dios de Monseñor Romero, tesis para la Maestría en Teología por la Universidad Centroamericana José Simeón Cañas (UCA), San Salvador, 1999.

Monseñor Óscar A. Romero, Homilías, Tomos I a VI, UCA Editores, San Salvador, 2006. 